\title{
Karşılaştırmalı Yerel Yönetimler Analizi: İngiltere ve Türkiye Örnekleri
}

\author{
DOI: 10.26466/opus.735795
}

\author{
Yakup Bulut* - Muzaffer Bimay ** \\ *Prof. Dr., Gaziantep Üniversitesi \\ E-Posta yakupbulut@hotmail.com ORCID: \\ * Dr. Öğr. Gör., Batman Üniversitesi \\ E-Posta: muzafferbimay@gmail.com \\ ORCID: $\underline{0000-0002-6742-2852}$

\section{Öz}

Sosyo-kültürel yapı açısından çok farklı olmakla beraber köklü devlet gelenekleri açısından oldukça fazla yönetim deneyimine sahip olan İngiltere ve Türkiye'nin yerel yönetim sistemini karşılaştırmayı amaçlayan bu çalışma, bu iki ülkede uygulanan yerel yönetim sistemlerini, yapı, görev ve yetkileri bakımından farklı ve benzer yönlerini, merkez yerel ilişkilerini, idari, mali, denetim ve özerklik boyutların, desantrilize düzeylerini ele almaktadır. Tarihsel süreçte ve günümüzde merkezîleşme ve yerelleşme tartışmalarının çokça yaşandiğı bu ülkelerde yerel yönetimlere ilişkin yasal ve anayasal düzenlemelerin ne olduğu, uygulamada yerel yönetimlerin ne kadar etkin olduğu görev, yetki, kaynak, harcama düzeylerinin nasıl bir seyir izlediği ortaya konmaktadır. Ayrıca demokrasi açısından da yerel yönetimleri ne anlam taşıdı̆̆ı ve bu ülkelerde yerel yönetimlerin demokratiklik boyutunun nasıl bir seyir izlediği de belirtilmektedir. Dolayısıyla çalışmada Türkiye ve İngiltere yerel yönetim sistemleri karşılaştırılmakta, benzer ve farklı yönleri ortaya konmaktadır. Bu bağlamda öncelikle yerel yönetimlerin günümüz yönetim sistemleri açısından nasıl bir anlam kazandı̆̆ına kısaca yer verildikten sonra, dünyada yerel yönetimlerin nasıl bir gelişim sağladığı ve nihayetinde Ingiltere ve Türkiye'de nasıl bir yerel yönetim sisteminin varlı̆̆ı tartışılacaktır.

Anahtar Kelimeler: Karşılaştırmalı Yerel Yönetim, Türkiye, İngiltere 


\title{
A Comparative Analysis Of Local Administration: Exmples Britain And Turkey
}

\begin{abstract}
This study aiming at comparing local government systems between Turkey and the UK that have longestablished state traditions in spite of different social and cultural structures, deals with different and similar aspects, center-local relations, administrative, financial, control and autonomy dimensions, and decentralized levels by comparing the local government systems implemented in both countries in terms of their structure, duties and powers, In these countries where centralization and decentralization discussions have been experienced a lot in the historical process and today, what the legal and constitutional regulations regarding local governments are, how effective local governments are in implementation, the course of their duties, powers, resources and expenditure levels are revealed. In addition, the meaning of local governments in terms of democracy and the course of the democratic dimension of local governments in these countries are also stated. Therefore, in this study, local government systems in Turkey and the UK are compared and similar and different aspects are unveiledIn this context, after briefly emphasizing how local government systems have had a meaning within the present administrative systems, it is argued how much local governments have developed and ultimately how the local governments emerged both in Turkey and the UK.
\end{abstract}

Keywords: Comparative Local Government, Turkey, England (UK) 


\section{Giriş}

Devletin idari ve bölgesel bölünmesinin temel amacı, halkın ihtiyaçlarını karşllayan en uygun ve etkili kamu yönetim sistemini sağlamaktır (Vodyanitskaya, 2016). Yerel yönetimlerin ortaya çıkış amacı da budur. Halka en yakın birimler olarak, yerel halkın ihtiyaçlarını karşılamak amacıyla demokratik kriterlere uygun olarak örgütlenen ve demokrasinin en canlı mekanizması olarak siyasal, ekonomik, kültürel ve idari alanda faaliyet sürdüren özerk kuruluşlar olarak yönetim sitemleri içinde yer almaktadır (Stigler, 1957; Lundın, 2015; Zhumashov, 2016; Mashamaite ve Lethoko, 2018; Koçak, 2017; Keleş, 1998). Her ne kadar homojen olmayan ülke nüfusları dikkate alınarak, özellikle üniter yapıları açısından özerk yerel yönetimlerin gelişmesi bir tehdit olarak görülse de günümüzde yerel özerkliklerin daha etkin hale gelmesi çoğu ülke tarafından benimsenmiş durumdadır (Eryılmaz, 2015, s.121-122; Gözler, 2010, s.45). Yerel yönetimlerin tarihsel olarak federe tipi yapılanmaya sahip ülkelerde gelişme gösterdiği bilinse de, üniter yapıya sahip İngiltere ve Türkiye'de de idari bakımdan yerinden yönetimin bir türü olarak önemli bir yere sahip olduğu söylenebilir. Avrupa Birliği (AB) üyesi olan ve Anglo-Sakson yerel yönetimi gibi köklü bir yerel yönetim geleneğine sahip olan İngiltere, parlamenter sisteme dayalı, güçlü bir merkezi yapıya sahip, geleneksel ve teamülü bir Anayasa çerçevesinde geliştirdiği hukuk devleti anlayışını yerel yönetimlere de yansıtmış, karmaşık yapısına rağmen alt yapısı sağlam bir demokratik kurum olarak yerel yönetimleri güçlendirmiştir. 1980 sonrası ortaya çıkan Yeni Sağ politikaları ve 1997 sonrası İşçi Partisi ve koalisyon hükümetlerinin devletin ve kamu yönetiminin yeniden yapılanma sürecinde merkezi güçlendirme adına yaptıkları reformlara rağmen yerel yönetimler, yerelleşmelerini sürdürmüşlerdir.

Türkiye'de ise 2000 öncesi İngiltere'deki yerelleşmeye göre arzu edilen seviyede olmamakla beraber, özellikle 2004 ve sonrası yerel yönetimler alanında yapılan reformlarla sürdürülen demokratikleşme ve yerelleşme çabaları, yerel yönetimlerin yapısal, işlevsel, vesayet ve özerkliğinin yeniden tanımlandığını ve mali açıdan merkeze bağımlılığı azaltıldığı söylenebilir.

Tarihsel birikime ve siyasi yapıların değişimine göre yerel yönetim yapılarının da bu iki ülkede nasıl bir değişim geçirdiğinin belirlenmesi, gerek literatüre gerekse uygulamaya önemli katkı sağlayacaktır. Özellikle yerel yönetimlerde katılımcı modellerin hayata geçirilmesi konusunda yol gösterici 
bir takım özelliklerin dikkatlere sunulması amaçlanmıştır. Çalışmada betimleyici bir yöntemle, literatür bilgilerinden yola çıkılarak karşılaştırmalı bir analiz yapılmaktadır.

\section{Yerel Yönetimlerin Kazandığı Anlam}

Eski Yunan ve Roma kentlerinden günümüze kadar olan süreçte, artan nüfus ve değişen siyasi ve sosyal süreçler, beraberinde yerel yönetimler alanında da sürekli değişim ve dönüşümleri getirmiştir (Görmez, 2015, s.3-5). Özellikle Sanayi Devriminden sonra kentlerde artan nüfus nedeniyle hizmet çoğulculuğunun ortaya çıkması, hizmette etkinlik ve verimliliği esas alan liberal yaklaşımlar, yerel yönetimlerin önemini artırmış ve onları daha etkin ve daha demokratik olmaları açısından çeşitli arayışlara sevk etmiştir (Keleş, 1998, s.34). Sanayileşme ile birlikte teknolojinin sosyal ve ekonomik alanda kullanımının giderek artması, yürütülen kamu hizmetlerinin çeşitlenmesi ve artması, kamu yönetimlerinin "kamu hizmeti veya hizmet devleti" ile karakterize edilmesi, kapitalizmin ortaya çıardığı krizler gibi birçok sorun, "sosyal devlet ve refah devleti" uygulamaları ile aşılmaya çalışılmıştı (Eryılmaz, 2015, s.48-52; Sezer ve Vural, 2010, s.205-206; Ökmen, Baştan ve Yılmaz, 2004, s.25). Ancak, özelikle 1971 petrol krizi ve sonrasında sorgulanan refah devlet anlayışı etkinliğini kaybetmiş ve kamu yönetimine ilişkin yeni arayışlar başlamıştır. Devlet yönetiminde krizlerin aşılması için, yeni bir kamu yönetimi anlayışına ve bu çerçevede devletin küçülmesine (minimal devlet), özel sektörün de devreye girmesine ve piyasa mekanizmasının işlemesine ihtiyaç duyulduğu görüldü. Bu gelişmeler çerçevesinde ortaya çıan yeni kamu yönetimi anlayışı ve devletin rolündeki değişim, desantralizasyonu ve yerel yönetimlerin yapı ve fonksiyonlarında kapsamlı bir yeniden yapılanmayı beraberinde getirmiştir (Ökmen, vd. 2004, s.25-26). Özellikle 1980 sonrası "neo-liberal politikaları", "devletin küçültülmesi ve etkinleştirilmesi" ve "desantralizasyon" (yerelleşme) politikaları, "iktisadi kaynakların rasyonel, akılcı ve verimli kullanımı" gibi konularda, önemli bir paradigma değgişiminin yaşandığı görülmektedir. Bu değişim, hem merkezi yönetimlerin hem de yerel yönetimlerin hizmet sunum anlayışlarını da değiştirmeye başladığı bir dönemdir (Çukurçayır ve Eşki, 2001, s.90-95). Özellikle merkezi yönetimler, giderek farklılaşan, yerelleşen ve karmaşıklaşan kamu hizmetlerini tek başlarına yapamayacaklarını görmeye başlamışlardır. Bu bağlamda merkezi yönetimler, 
yerel nitelikli kamusal mal ve hizmetlerin, devlet tüzel kişiliği dışındaki kamu tüzel kişileri tarafından da yapılması çabasına girmişlerdir (Nadaroğlu, 1986, s.3-20). Başka bir ifadeyle, merkezi yönetim ile yerel yönetim ilişkilerinin yetki, kaynak, katılım, şeffaflık, hesapverebilirlik, denetim, hizmet ölçeği ve kapasite gibi konularda yeniden yapılandırılması zorunlu olmuştur (Gül ve Özgür, 2004, s.162).

Bugün yerel yönetimler görev ve fonksiyonları açısında önemli işlevler görmektedir. Merkezi yönetimlerle kıyaslandığında, yerel yönetimlerin, katılım, denetim, özerklik, eşitlik, etkinlik ve ortak yarar gibi demokrasinin temel değerlerini hayata geçirme noktasında daha etkin olduğu ve özelikle yerel ölçekte kamu hizmetleri açısından daha isabetli kararlar aldığı söylenebilir (Görmez, 2015, s.11-23). Ayrıca enformasyon, nezaket, güvenlik, güvenilirlik, fiziksel unsurlar, erişilebilirlik, vatandaşı anlama ve yeterlilik konusunda müşteri odaklı yönetim tartışmaları çerçevesinde "kurumsal yönetişim"e dayalı etkin ve verimli hizmet sunabilmektedir (Ökmen ve Parlak, 2015, s.135136). Dolayısıyla yerel yönetimler birçok hizmetin vatandaşa sunulması noktasında çabukluk ve kolaylıklar sağlar (Kaypak, Yılmaz ve Bimay, 2017, s.1799). Bu çerçevede demokrasinin temel eğitim kurumu olarak da görülen yerel yönetimlerin (Wickwar, 1970; Görmez, 1989), demokratik değerlerin hayata geçirilmesinde etkin olduğu, yerel düzeyde demokrasi sağlanmadan ulusal düzeyde demokrasinin sağlanamayacağı ileri sürülmektedir (Hill, 1974). Dolayısıyla günümüzde desantralizasyon düşüncesi ve hizmette yerellik ilkesine bağlı olarak (Eryılmaz, 2015, s.123-126) hizmetlerin etkin ve verimli bir şekilde gerçekleşmesi, halkın yerel kararlara katılımının sağlanması, kamu hizmetlerinin yerel düzeyde ve yerel halkın ihtiyaçlarına daha etkin cevap verebilmesi, ancak yerel yönetimlerin etkinleştirilmesi ile olacağ1 söylenebilir.

\section{Dünyada Yerel Yönetimler}

Yerel yönetimlerin Eski Yunan ve Roma kent yönetimlerine kadar gittiği söylenebilir. Goodnow (1887, s.638), Normandiya'nın İngiltere'yi fethi zamanında yerel yönetimlerin biçimlendiğini, Henry Pirenne (1994, s.18-58) ise, Batı Avrupa'da burjuvazinin kentlerde elde ettiği gücü kullanarak yerel yönetim örgütlemesini ortaya çıkardığını belirtmektedir. Bugünkü anlamda yerel yönetimlerin temeli ise Ortaçağ' da burjuvazinin de etkisiyle oluşturulan 
"komünler" sayesinde gerçekleştiği bilinmektedir (Çukurçayır, 2012, s.96). Bu dönemlerde yerel nitelikli genel ve ortak hizmetler, genellikle kiliseler, vakıflar ve esnaf dernekleri tarafindan yerine getirmekteydi (Aydınlı, 2004, s.83). Bununla beraber, "vatandaş", "kent", "kentli" ve "uygarlık" kavramlarının birlikte zikredildiği sanayileşme ve modernleşme aşamalarından sonra, yönetime katılma, kurumsallaşmış yerel birimler ve etkin yerel yönetim uygulamaları, daha modern bir yerel yönetim anlayışını ortaya çıkarmıştır (Ökmen ve Parlak, 2015, s.66). Diğer bir ifade ile yerel yönetimler demokrasinin gelişmesine ve yaygınlaşmasına önemli katkı sağlamış, hatta belediyeler, devletin bir birimi olarak değil, sivil toplumun bir parçası olarak görülmeye başlanmıştır ki, özellikle hizmette çoğulculuk ve liberal yaklaşımlar, yerel yönetimlerin etkin kuruluşlar olmasına katkı sağlamıştır. (Görmez, 2015, s.9; Ayhan, 2008, s.105). "Desentralizasyon" ve "subsidiyarite" (subsidiarity)" kavramları ile açıklanan bu yeni anlayış, $A B D$ ve $A B^{\prime}$ nin temel altyapısını oluşturmuş, 1992 yılında imzalanan Maastricht Antlaşmasıyla hukuksal nitelik kazanmıştır (Sakal, 2000, s.121).

Keleş (1998, s.69), tarihsel süreç içerisinde dünyada oluşan yerel yönetim sistemlerini dört model etrafında açklamaktadır:

Fransız Modeli: Fransa'dan başka İtalya, İspanya, Portekiz, Türkiye, Belçika ve Yunanistan' da uygulanan bu sistemde yerel yönetimlerin Anayasa ile güvence altına alınmış belli bir statüsü bulunmaktadır.

Anglo-Sakson Modeli: Anayasal bir statüye sahip olmayan ülkelerde bulunan ve Anglo-Sakson geleneğinin hâkim olduğu, yasayla kurulup yasayla kaldırılabilen yerel yönetimlerdir. İngiltere gibi tamamen parlamentonun etkisinin fazla olduğu ülkelerde görülür. Klasik örneğini oluşturan İngiltere d1şında ABD, Avustralya, Kanada, Yeni Zelanda bu modeli uygulayan diğer ülkelerdir.

Kuzey ve Orta Avrupa Modeli: Yerinden yönetim geleneğine sıkı sıkıya bağlı ve demokrasiye artan oranda önem veren bu gruba dahil ülkelerde yerel yönetimler, anayasal bir statüye sahip olmanın yanında çok geniş bir yönetsel ve mali özerklikten de yararlanırlar. Anglo-Sakson modeline benzeyen bu model İsveç, Norveç ve Danimarka'nın yanı sıra Almanya, Avusturya, İsviçre, Hollanda ve Japonya' da uygulanmaktadır. 
Orta ve Doğu Avrupa (Eski Sosyalist Blok) Modeli: Sovyetler Birliği'nde Lenin ve Stalin tarafından kurulup geliştirilen bu modelde, çözülme sürecini büyük ölçüde tamamlamış bulunan Orta ve Doğu Avrupa'nın Sosyalist Bloku ülkeleri olan Yugoslavya, Arnavutluk, Bulgaristan, Macaristan, Polonya, Romanya ve Çekoslovakya yer almaktadır.

Bugün cari olan modeller farklı olsa da genel olarak yerel yönetimlerin merkezi yönetimlere göre çok daha etkin konumda olduğu, özellikle kamu hizmeti sunumu ve halka yakınlık, toplumsal dönüşümleri ve siyasal anlamda yöneten yönetilen yakınlaşmasını sağlama noktasında çok daha etkili olduğu söylenebilir.

\section{İngiltere ve Türkiye'de Yerel Yönetimlerin Karşılaştırılması}

Burada İngiltere ve Türkiye' de yerel yönetimlerin tarihsel ve siyasal süreçleri, örgüt yapıları, mali ve denetim şekilleri ve verdikleri hizmetler açısından karşılaştırılması yapılmaktadır.

\section{Tarihsel ve Siyasal Süreçleri Açısından Karşılaştırma}

İngiltere ve Türkiye, siyasi ve idari gelenekler açısından oldukça farklı iki ülkedir. Dolayısıyla yerel yönetim yapılarının farklı olması da doğaldır. Ancak özellikle yerel politika ve hizmet sunumu bakımından dikkate alınacak bazı model uygulamaların olduğu ve bunların incelenmesi, iki ülke yerel yönetimlerinin karşılaştırmasının faydalı olacağı kanaatini vermektedir. Diğer bir ifade ile her iki ülkenin yerel yönetimlerini, tarihsel süreçte yapısal, işlevsel ve siyasal açıdan karşılaştırmak ve modellerini ortaya koymak, iyi uygulama örnekleri ve farklı yerel yönetim anlayışlarını görme fırsatı sağlayacaktır.

\section{Ingiltere'de Yerel Yönetimlerin Tarihsel ve Siyasal Süreci}

Anayasal ve siyasi adı "Büyük Britanya ve Kuzey İrlanda Birleşik Krallığı” olan İngiltere, dört farklı ada ülkesinin birleşmesinden oluşan Birleşik Krallıktır (Oakland, 2002, s.10). 1707'de, İngiltere, Galler ve İskoçya'nın birleşmesi ile Büyük Britanya, 1800'de Büyük Britanya ile Kuzey İrlanda'nın bir araya gelmesi ile de Birleşik Krallık oluşmuştur (Karasu, 2004, s.87). Birleşik Kral- 
lıkta yerel yönetim geleneği, Anglo-Sakson dönemine kadar uzanan ve yüzyıllardır değişik formlarda devam eden oldukça köklü ve eski bir sisteme sahiptir (Oakland, 2002, s.65). Yerel yönetimlerin, bu dönemde eyaletlere ve onlara bağlı küçük yerleşim birimlerine ayrıldığı ifade edilmektedir (Byrne, 1985, s.10-12). 1066' dan sonra I. William zamanında güçlü bir merkezi yönetimin kurulması sonucu yapılan düzenlemeler ile parish (köy), borough (il) ve county (eyalet) gibi yönetim birimlerinin kurulduğu görülmektedir (Türkoğlu, 2009, s.50). Yazılı yasalardan çok, gelenek ve mahkemelerin içtihat kararlarının geçerli olduğu İngiliz yerel yönetimlerinde, merkez ve yerel ayrımı, Magna Carta'ya (1215) kadar uzanmaktadır (Ökmen ve Parlak, 2015, s.284). İngiliz yerel yönetimleri 1601 yılında çıkarılan yasa ile belli bir fonksiyonel ve özerk bir yapıya kavuşmuş olmasına rağmen, bu özerklik sadece kendilerine ayrılan alanda kural koyma ve iş yapabilme ile sınırlı kalmıştı (Yamaç, 2014, s.1). 1640 yılındaki Burjuvazi Devrimi'nden sonra burjuvazi kendi ekonomik çıkarlarını korumak için siyasi iktidarı soylulara bırakmış, ancak soyluların iktidarı kullanabilme yetersizlikleri nedeniyle birçok yerel hizmet "yeomenler ve squireiler" denilen küçük toprak sahibi yerel zümrelere devredilmişti (Engels, 2010, s.44-54). 1760 yılından itibaren mevzuat çabalarının yetersizliği nedeniyle zayıflayan yerel yönetim birimleri (Güler, 2013, s.77-78), 19. yüzyılda ekonomik devrimin ortaya çıkardığı sınıf çatışmalarına rağmen yine de ayakta kalabilmişlerdi (Hobsbawm, 1987, s.61). Bunun en önemli sebebi, Fabian, Beatrice Webb ve J. Stuart Mill'in yan sıra Turgot ve Bentham gibi düşünürlerin yerel hizmetlere ilişkin düşünce ve uygulamaları olmuştur (Keleş, 1998, s.35-37; Ayhan, 2008, s.104; Aydınlı, 2004, s.73). 1835 yılında kabul edilen "Belediye Şirketleri Yasası" ile belediyelerin kurulması, 1894 yılında belediye meclislerinin kurulması, 1888 ve 1889 yılında çıkarılan yasayla İrlanda ve İskoçya için yerel yönetimler ve belediye encümenleri yasalarının çıkarılarak söz konusu yönetimlerin halk tarafından belirlenmesi esasına geçilmesi, dönemin önemli gelişmeleri olarak görülebilir (Sandford, 2016, s.11; Byrne, 1985, s.28).

İkinci Dünya Savaşı sonrasında kentleşme ile beraber güçlenen ve yeni bir çerçeveye oturtulan (Sakal, 2000, s.127) yerel yönetimlerin bugünkü yapısı, 1972'de yapılan ve 1 Nisan 1974'den itibaren yürürlüğe konulan Yerel Yönetimler Yasası, 1985 ve 1986 yılında yapılan düzenlemelerle belirginleşmiştir. Böylece yerel yönetimler, yazılı yasalara tabi kuruluşlar olarak varlık göstermişlerdir (Worthy, Amos, Hazell ve Bourke, 2011, s.12). Söz konusu yasalarla 
yerel yönetimler, nüfus yoğunluğu ve sosyo-ekonomik koşullara göre yeniden düzenlenmiş ve mevcut yerel yönetim birimlerinin sayısı azaltılarak, birinci kademe olarak il (county), ikinci kademe olarak bölge (district), üçüncü kademe olarak da köyler (parishes) yeniden oluşturulmuştur (İnaç ve Ünal, 2006, s.126). Ancak Yeni Kamu Yönetimi anlayışının geliştiği 1970'li yıllardan itibaren Muhafazakâr Sağın öncülüğünü yapan Thatcher Hükümeti'nin etkisiyle yerel yönetimlerin merkeze bağımlılı̆̆ azalmıştır (Coulson, 2004, s.471; Ateş ve Demirel, 2014, s.4; Kızıler ve Çetinkaya, 2015, s.139). 1985 yılında, 1965 yılından beri Londra Büyükşehir Meclisi Sistemi olarak uygulanan Londra Yerel Yönetim Birimine ait yetkiler, ilçe belediyelerine aktarılarak söz konusu sistemin uygulamasına son verilmiştir (Tortop, 1992, s.3-8). 1990'lardan sonra yerel baskılar nedeniyle yapılan referandumlarla yerel yönetim sisteminde değişime gidilmiş ve Londra merkezli Büyük Britanya Parlamentosu'nun yanında Kuzey İrlanda, İskoçya ve Galler'de seçimle işbaşına gelen yerel meclislerin (parlamentolar) kurulması ile birlikte merkezden yerele diş politika, savunma ve ulusal güvenlik, ekonomi ve para politikası dışında kalan sağlık, eğitim, kültür, çevre ve ulaşım gibi tüm hizmetlerde yetki devri sağlanmıştır (Government Of United Kingdom, [GOV.UK], 2019; Wollmann, 2012, s.44). Hatta Kuzey İrlanda'da bir parlamento ve bu parlamento tarafından atanan başbakan ve bakanlardan oluşan bir hükümet bulunmakta ve bu hükümet aracllı̆̆yla tüm hizmetler yürütülmektedir (Northern Ireland Exceutive [NIE], 2019).

1997' de iktidara gelen Blair Hükümeti (İşçi Partisi) ile birlikte merkeziyetçiliğin terk edilmesi, yerel güçlere yönelik yetki devrinin arttırılması ile yerelleşmenin ve sivil inisiyatifin hayata geçirilmesi konusunda önemli düzenlemeler yapılmıştır (Ateş ve Demirel, 2014, s.4). Hükümet, Avrupa Yerel Yönetimler Özerklik Şartını imzalayarak siyasal yerinden yönetim reformu ile Birleşik Krallığı oluşturan Galler, İskoçya ve Kuzey İrlanda'ya daha fazla yetki devri ve özerklik verilmesi maksadıyla referanduma gidilmiş ve bu halkoylamasıyla ülkenin geleceği konusu tartışmaya açılmıştır (Canpolat, 1999, s.319-321; Karasu, 2004, s.151-157). Bu dönemde, serbest piyasa ve özelleştirme gibi Muhafazakâr kanadın etkileri olmasına rağmen seçilmişlere ait meclislerin varlığı ve bu meclislerin sahip olduğu yetkilerin kullanımına ilişkin alanlar, İngiltere'nin üniter bir yapıdan çok yarı-federal bir ülke durumuna geçtiğini göstermekteydi (Coulson, 2004, s.471; Wollmann, 2012, s.44). Merkez-yerel ilişkileri konusunda yaşanan sıkıntılar nedeniyle İşçi Partisi, 
"Üçüncü Yol” felsefesiyle kamu hizmetlerinin niteliğini arttırarak hem orta sınıfın hem de iş dünyasının güvenilirliğini elde etmek için liberal çizgiye eğilim göstermeye başlamıştır (Ateş ve Demirel, 2014, s.2). Muhafazakâr partiler ile sol partiler arasında benzer çalışmalar olsa da gelinen noktada muhafazakâr partilerin yerel yönetimlere ilişkin reform çalışmalarında daha temkinli davrandıkları görülmektedir (Laffin, 2008, s.109).

2000 yılında yapılan yeni düzenlemeyle, 1980'lerde dönemin Thatcher Hükümeti tarafından sonlanan Londra yerel yönetim birimi, Londra Büyükşehir Belediyesi olarak yeniden kurulmuş, yerel yönetim sayılarında artış sağlanmış ve iç örgütlenmeleri türdeş hale getirilmiştir (Ökmen ve Parlak, 2015, s.285-286). Yine Yerel Yönetim Birliği, Bölge Kalkınma Ajansları Yasası ve Çevre Bakanlığı ile Ulaştırma Bakanlığı'nın birleştirilmesi bu dönemde atılan önemli adımlardır (Karasu, 2004, s.108). 2006 yılında konut, kentsel dönüşüm, planlama, yangın, kurtarma hususlarında görevli “İskan, Topluluklar ve Yerel Yönetimler" adlı bakanlık kurulmuştur (GOV.UK, 2019; Al, 2008, s.116-131). Son yıllarda da İngiltere'de hükümet çalışmaları genel olarak başta yerel yönetimler olmak üzere kamu hizmetlerine ilişkin reformlar üzerine odaklanmıştır (Laffin, 2008, s.109). Bu çalışmaların çoğu yerel yönetim reformu adı altında yeni ekonomik gelişmelere uyum sağlamak amacıyla yapilmaktadir.

İngiltere'de, yerel yönetimler parlamentonun denetim ve gözetimi altındadırlar. Yerel yönetimlerin yetki, görev ve sorumlulukların değiştirebilmekte veya başka bir birime aktarabilmektedir (Karasu, 2004, s.110). Bakanlıklar, yasalar çerçevesinde yerel yönetimlere bırakılmış olan görev ve yetkilerin uygulanma ve kullanılma durumunu çeşitli yollarla denetleyebilmektedir. 2000'li ylllardan itibaren kamu hizmetlerinin sunumunda yeni bir yaklaşım ortaya konmuştur. "En İyi Değer (Best Value)" rejimi olarak tanımlanan bu yaklaşıma göre yerel yönetimler tarafından sağlanan hizmetlerde kalite, standart, maliyet, etkililik, etkinlik ve tutumluluk amaçlanmış ve yerel otoritelerin tamamı bu uygulamaya dâhil olmuşlardır. Böylece bağımsız denetim kuruluşları, İngiltere Denetim Komisyonu ile birlikte yetki kullanma hakkını elde etmişlerdir (Yamaç, 2014, s.13).

\section{Türkiye'de Yerel Yönetimlerin Tarihsel ve Siyasal Süreci}

Türkiye'de yerel ve bölgesel oluşumların başlangıcı Osmanlıya dayanmaktadır. Osmanlı Devleti, tüm toprakları elinde tutabilmek için yerel ve bölgesel 
düzeyde farklı yönetim modellerine izin vermiştir (Güler, 2010, s.278). Bu dönemde, belediye hizmetleri ile mülki ve askeri hizmetler birlikte yürütülüyordu (Seyidanlıŏlu, 2010, s.2). Belediyeler kuruluncaya kadar, belediye işleri geleneksel kurumlar olan vakıflar ve kadılar tarafından yürütülüyordu (Tortop, Aykaç, Yaman, ve Özer., 2006, s.75). Yerel yönetimler alanında ilk gelişmeler ise 1808 'de Osmanlı Sadrazamı Alemdar Mustafa Paşa'nın Rumeli ve Anadolu ayanları ile imzaladığı ve merkeziyetçi yapının sınırlandırıldığ Sened-i İttifak ve 1833 yılında İstanbul'da uygulanmakta olan muhtarlık teşkilatının taşrada yaygınlaştırılmaya başlamasıyla gerçekleştirilmiştir (Gözler, 2000, s.3-4; Çadırc1, 1970, s.409-410). Köyler eski geleneksel yerel yönetimin devamı olmasına rağmen, "İl Özel İdareleri" ve "Belediyeler", Fransız yerel yönetim yapısı örnek alınarak örgütlendirilmiştir (Gözübüyük, 1971, s.121; Tortop vd., 2006, s.75). 1864 tarihli Vilayet Nizamnamesiyle eyalet sisteminden vilayet sistemine geçen Osmanlı Devleti, bu nizamname ile ilin genel yönetiminin yanı sıra il özel idarelerini de kurmuştur (Çiftepınar, 2006, s.124; Sobac1, 2005, s.33). Ayrıca 1913 tarihli İdare-i Umumiye-i Vilayet Kanunu'nda il özel idareleriyle ilgili temel hükümlere yer verilmiştir. 1929 yılında ise, 1426 sayılı yasa ile il genel yönetimi bütüncül bir mevzuata kavuşturulmuştur (Tortop vd., 2006, s.76).

Belediyelerle ilgili ilk düzenlemeler, Tanzimat'tan sonra başlayan Batılllaşma süreci ile azınlıklara yönetime katılma hakkı verilmesi konusunda dış devletlerin baskıları sonucu ortaya çıkmıştır. İmparatorluğun parçalanmasını engellemeye yönelik bu düzenlemelerle yerel alandan merkeze doğru bir kayma görülmüştür (Tunçer, 2011, s.139). 1854 yılında çıkarılan Şehremaneti Nizamnamesi Layihası ile İstanbul'da ilk belediye teşkilatı kurulmuştur. Bu teşkilatın başına bir Şehremini getirilerek İstanbul modern bir kent haline getirilmiş ve bu uygulama zamanla İstanbul dışında da yaygınlaştırlmıştır (Seyidanlıoğlu, 2010, s.26; Yaylı, 2009, s.29-40). Nitekim belediye teşkilatının kurulmasından üç yıl sonra İstanbul'un Beyoğlu ve Galata bölgelerine Altıncı Belediye Dairesi kurulması ve 1869 yılında Dersaadet Belediye Nizamnamesiyle tüm İstanbul'a yayılması bu gelişmelerin sonucunda gerçekleşmiştir. 1876 Anayasası, belediyelerin seçimle işbaşına gelecek meclisler tarafından yönetilmesini ve bunların kuruluş ve görevleri ile meclis üyelerinin seçim usullerinin yasayla düzenlenmesini öngörüyordu. Cumhuriyet döneminde, 1930 yılında çıkarılan 1580 sayılı Belediye Yasası, (Tortop vd., 2006, s.75-77), yerel yönetimler açısından en önemli bir düzenleme olduğu söylenebilir ki, 
yasa, yerel yönetimlerin örgütsel yapısı yanında görev, yetki ve sorumluluklarına geniş yer vermiştir (Güler, 1992, s.103).

1960'lı yıllardan sonra reform çalışmalarının ayrıntıll, bilimsel ve bir bütün içinde ela alınamayışı ülkemizde yerel yönetimlerle ilgili önemli bir gelişme sağlanamamıştır. 1963 yılında çıkarılan Merkezi Hükümet Teşkilatı Araştırma Projesi (MEHTAP), 1971 yılında özellikle İçişleri Bakanlı̆̆g'nın yeniden yapılandırılmasına yönelik İdari Reform Danışma Kurulu Raporu ve 1991 yılında Kamu Yönetimi Araştırma Projesi (KAYA) gibi hazırlanan değişik raporlar dişında ciddi bir çalışma ortaya çıkmamıştır (Sakal, 2000, s.128). 1978 yılında kurulan Yerel Yönetim Bakanlığı da merkezin yerel yönetimler üzerindeki etkisini arttırma yönünde atılan adımlardan öteye gidememiştir (Urhan, 2008, s.70).

1982 Anayasası ile 3030 sayılı Büyükşehir belediyelerine ilişkin yasal düzenleme ve 1984 yılında kurulan ilk büyükşehir belediyelerine kamu gelirlerinden daha çok pay verilmesi merkeziyetçiliğin zayıflatılmasına yönelik adımlar olarak kabul edilmektedir (Toksöz vd. 2009, s.39). 1987 yılında çıkarılan 3360 sayıl yasa ile günün değişen koşullarına uyum sağlayabilmek adına yerel yönetimler, büyük ölçüde değişikliğe uğramıştır (Keleş, 1998, s.137-138). 2000'li yıllardan sonra iç (hızlı kentleşme, ekonomik yapıdaki değişme, bölgesel eşitsizlik) ve diş (küreselleşme, $A B$ üyelik süreci) dinamiklerin tetiklemesiyle başlayan reform hareketleri 2004 yılında çıarılan 5216 sayılı Büyükşehir Belediyeleri Kanunu, 2005 yılında çıarılan 5393 sayılı Belediye Kanunu ve 5302 sayılı İl Özel İdaresi Kanunu ile çeyrek yüzyıllık parçalı uygulamalar yasal hale gelmiş ve yerel yönetimler önündeki Anayasal ve yasal engeller kaldırılmıştır (Güler, 2013, s.11). 1996 yılında başlayan, 1998 y1lında Mahalli İdareler Reform Yasa Tasarısı olarak belirlenen ve 2004 yılında 5227 sayılı yasa olarak mecliste kabul edilen Kamu Yönetimin Temel Illkeleri ve Yeniden Yapılandırılması Hakkındaki Kanun, tüm devlet örgütlenmesini değiştireceği endişesiyle Cumhurbaşkanı'nın itirazları ve muhalefetin tepkileri sonucu iptal edilmiştir. Aslında yerel yönetimlerin özerkliğiyle ilgili hayata geçirilmeye çalışılan düzenlemelerin çoğu, ulus-devleti parçalayacağ endişesi ile sürekli engellenmiştir (Eroğul, 1999, s.162). 2012 ve 2013 yıllarında kabul edilen 6360 ve 6447 sayılı yasalar da her ne kadar "bütün şehir" ve "yeni büyük şehir" yönetimleri konusunda bir yeniden yapılandırma olarak değerlendirilse de yerelleşemeden çok yerelin merkezileşmesi olarak yorumlanmıştır. 


\section{Yönetim Modelleri Açısından Karşılaştırma}

Bir ülkenin yerel yönetimleri o ülkenin siyasal ve yönetsel yapısının durumuna bağlı olarak değişim gösterir. Bu sebeple Tablo 1'de İngiltere ve Türkiye'nin siyasal ve yönetsel yapıları karşılaştırılırken Tablo 2'de yerel yönetim yapıları karşılaştırılmaktadır.

İngiltere'de yazılı bir anayasa olmamasına rağmen, siyasal ve yönetsel gelenekleri, kendine özgü bir güçler ayrılığı anlayışını ortaya çıkarmıştır (Arıbaş, 2015, s.4). Birleşik Krallık özelinde sürdürülmeye çalışılan monarşik yapının, yasama sisteminde oluşturduğu farklılıklar ve bu çerçevede ortaya çıkan parlamenter hükümet sistemi, güçler ayrilığını dengelemektedir (Kama, 2016, s.161). 8. yüzyılda uygulamaya başlanılan "Westminster" modelini esas alan normatif, geleneksel ve Kraliyete ait birtakım sembolik öğeler içeren bu sistemde, güçlü iktidar, iki meclislilik, iki partili sistem, çoğunlukçu seçim sistemi, parlamento egemenliği, temsili demokrasi ve genel oy sistemi olan merkeziyetçi yönetim tarzı bulunmaktadır. Merkezi yönetim; başbakan, kabine, kabine komisyonları ve alt komisyonları, bakanlıklar ve kurumlar arası komitelerden oluşmaktadır. Merkezdeki koordinatör kurumlar Kabine Ofisi ve Hazine'dir. Hukuk sistemi, hukukun bir bütün olduğu, "ortak hukuk (common-law)" sistemidir (Karasu, 2004, s.91; Özen, 2008, s.16). Yazılı bir anayasa olmadığı için ortak hukuk sisteminde ilke olarak devlet dâhil, hukukun tüm özneleri eşit kabul edilmekte, devlet ile bireyler arasındaki ilişkiler ortak hukuk kurallarına ve sözleşmelere dayandırılmaktadır (Department of Economic ve Social Affairs, 2006, s.5).

Tablo 1. Ingiltere ve Türkiye'nin Siyasal ve Yönetsel Yapılarının Karşılaştırılması

\begin{tabular}{lll}
\hline & İniltere & Türkiye \\
\hline Devlet Yapıları & Üniter & Üniter \\
\hline Siyasal Yapıları & $\begin{array}{l}\text { Parlamenter Demokrasi ve Anayasal } \\
\text { Monarşi, Kuvvetler Ayrılığı }\end{array}$ & $\begin{array}{l}\text { Cumhurbaşkanlığı Hükümet Sis- } \\
\text { temi, Kuvvetler Ayrılığı }\end{array}$ \\
\hline İdari Yapıları & $\begin{array}{l}\text { Siyasal açıdan merkeziyetçi, } \\
\text { İdari yönden adem-i merkeziyetçi }\end{array}$ & $\begin{array}{l}\text { Siyasal ve idari yönden merkezi- } \\
\text { yetçi }\end{array}$ \\
\hline Hukuk Sistemi & Anglo-Sakson Geleneği & $\begin{array}{l}\text { Kıta-Avrupası Geleneği (Fransız } \\
\text { Modeli) }\end{array}$ \\
\hline Yasama Düzeni & $\begin{array}{l}\text { Parlamento egemenliğini esas alan } \\
\text { “Westminster" modeli çift kanatlı par- }\end{array}$ & Tek Kanatlı (TBMM) \\
& $\begin{array}{l} \\
\text { lamento (Lordlar Kamarası ve Avam } \\
\end{array}$ & \\
& Kamarası) & \\
\hline
\end{tabular}




\begin{tabular}{|c|c|c|}
\hline Yürütme Düzeni & $\begin{array}{l}\text { Taç (Kral veya Kraliçe), Özel Konsey, } \\
\text { Bakanlar Kurulu, Başbakan ve Kabine }\end{array}$ & Cumhurbaşkanı \\
\hline Yargi Düzeni & $\begin{array}{l}\text { Anglo-Sakson "ortak hukuk" (com- } \\
\text { mon-law) sistemi, } \\
\text { İngiltere, Galler, İskoçya, Kuzey İr- } \\
\text { landa'da birbirinden farklı hukuk sis- } \\
\text { temleri } \\
\text { Anayasal kaynaklar: yasalar, mah- } \\
\text { keme kararları, hukukun temel ilke- } \\
\text { leri, parlamento içtüzüğü ve anayasa } \\
\text { gelenekleri }\end{array}$ & $\begin{array}{l}\text { Türk Milleti adına bağımsız ve ta- } \\
\text { rafsız mahkemelerce kullanılır. } \\
\text { Adli Yargı ve İdari Yargı } \\
\text { Anayasal kaynaklar: Anayasa, ka- } \\
\text { nun, tüzük, yönetmelik ve Anayasa } \\
\text { Mahkemesi kararları }\end{array}$ \\
\hline Devlet Teşkilatlanması & $\begin{array}{l}\text { Merkezi Hükümet ve Parlamento, } \\
\text { Londra Bölgesel Parlamento, } \\
\text { Galler, İskoçya ve Kuzey İrlanda Parla- } \\
\text { mentoları, Yerel Meclisler }\end{array}$ & $\begin{array}{l}\text { Merkezden Yönetim-Yerinden Yö- } \\
\text { netim }\end{array}$ \\
\hline
\end{tabular}

Kaynak: TBMM, 2019; T.C. Cumhurbaşkanlığı, 2019; Gözübüyük, 1971; İnaç ve Ünal, 2006; Karasu, 2004; Department of Economic and Social Affairs, 2006; Laffin, 2008; Martin, 2011; Nadaroğlu,1986; Şengül, 2014; Özen, 2008; Wollmann, 2012; Tortop vd., 2006; Sandford, 2016; Ökmen ve Parlak, 2015; GOV.UK,2019; Eryılmaz, 2015.

Türkiye yazılı anayasası olan üniter yapılı bir devlettir ve Anaysa gereği (m.3) "Türkiye Devleti, ülkesi ve milletiyle bölünmez bir bütündür". Yönetim sitemi olarak 2018'e kadar parlamenter sitemle yönetilmekle beraber, bu tarihte yapılan Anayasal değişiklik ile "Cumhurbaşkanlığ1 Hükümet Sistemi"ne geçmiştir. İdari taksimat açısından il sistemine dayanmaktadır. Anayasa, "Türkiye, merkezî idare kuruluşu bakımından, coğrafya durumuna, ekonomik şartlara ve kamu hizmetlerinin gereklerine göre, illere; iller de diğer kademeli bölümlere ayrılır" (m.126) hükmünü koymuştur. İdari bakımdan yerinden yönetim ilkesine uygun olarak "hizmet" ve "yer yönünden" ikili ayrıma tabi tutulmuştur. Yerel yönetimler; "ìl Özel İdaresi", "Belediye" ve "Köy" olarak belirlenmiştir. Halen Türkiye'de 81 il, 923 ilçe ve 35.000'den fazla köy yönetim birimi bulunmaktadır. Yerel yönetimler üzerinde merkezî yönetimin vesayet denetimi olmakla beraber özellikle 2004 ve 2005'de çıkar1lan yerel yasalarla vesayetin "hukuka uygunluk" açısından yapılacağı hükme bağlanmıştır. Halen özerklik konusunda kısıtlı (Tortop vd., 2006) olduğu söylenebilse de bu kısıtlılığın daha çok mali özerklik bağlamında olduğu söylenebilir. Özellikle gelişen ve çeşitlenen yerel hizmetlerin tam anlamıyla yerine getirilebilmesi için yerel yönetimlerin istenen mli kaynaklara sahip olduğu söylenemez. 


\section{Örgütsel ve İşlevsel Yapılarn Açısından Karşılaştırma}

Halka en yakın birim olarak tanımlanan yerel yönetimler, Türkiye ve İngiltere'nin siyasal ve yönetsel durumuna bağlı olarak değişiklik göstermektedir. Aşağıdaki tabloda bazı açılardan iki ülke yerel yönetimleri karşılaştırmaktadir.

Tablo 2. Ingiltere ve Türkiye'nin Yerel Yönetim Sistemlerinin Karşılaştırılması

\begin{tabular}{|c|c|c|}
\hline & İngiltere & Türkiye \\
\hline $\begin{array}{l}\text { Yerel Yönetimler } \\
\text { ve Organları }\end{array}$ & $\begin{array}{l}\text { 1- Birinci kademe İl: County -Başkan ve } \\
\text { Meclis } \\
\text { 2- İkinci kademe Bölge: District-Başkan ve } \\
\text { Meclis } \\
\text { 3- Üçüncü kademe Köy yönetimi: Parishes } \\
\text {-Başkan ve Meclis } \\
\text { 4- Büyük Londra Yönetimi: Başkan ve Mec- } \\
\text { lis, } \\
\text { Londra'da üst kademe yönetiminde Büyük } \\
\text { Londra Otoritesi (Greater London Autho- } \\
\text { rity), alt kademede ise Londra Şehir Meclisi } \\
\text { ve ilçe-borough meclisleri vardır. }\end{array}$ & $\begin{array}{l}\text { 1-İl Özel İdaresi: Vali, İl Genel } \\
\text { Meclisi, İl Encümeni } \\
\text { 2-Belediye: Belediye Meclisi, Bele- } \\
\text { diye Başkanı, Belediye Encümeni } \\
\text { 3-Köy: Muhtar, İhtiyar Heyeti, } \\
\text { Köy Derneği }\end{array}$ \\
\hline $\begin{array}{l}\text { Yerel Yönetimlerin } \\
\text { Dayanakları }\end{array}$ & $\begin{array}{l}\text { Anayasal dayanağı yok. } \\
\text { Görev ve yetkiler kanunlarla düzenlenmiş- } \\
\text { tir. }\end{array}$ & $\begin{array}{l}\text { Anayasal dayanağı var. } \\
\text { Görev ve yetkiler kanunlarla dü- } \\
\text { zenlenmiştir. }\end{array}$ \\
\hline $\begin{array}{l}\text { Yerel } \\
\text { Yönetimlerin } \\
\text { İşlev } \\
\text { ve } \\
\text { Faaliyet Alanları }\end{array}$ & $\begin{array}{l}\text { Eğitim (üniversite öncesi tüm eğitimler), } \\
\text { sağlık, sosyal hizmetler, konut, ulaşım, kül- } \\
\text { türel hizmetler, kütüphaneler, şehir ve kır- } \\
\text { sal alan planlaması ve çevre gibi temel hiz- } \\
\text { metleri, polis, itfaiye ve tüketicinin korun- } \\
\text { ması, karayolları, eğlence }\end{array}$ & $\begin{array}{l}\text { Altyapı hizmetleri, eğitim, sağlık, } \\
\text { kültür, ekonomi ve ticaret, konut, } \\
\text { çevre, şehir içi ulaşım, sosyal hiz- } \\
\text { metler }\end{array}$ \\
\hline $\begin{array}{l}\text { Yerel Yönetimlerin } \\
\text { Yetki ve Görevleri }\end{array}$ & $\begin{array}{l}\text { Yerel yönetimlerin yetkilerini ve görevlerini } \\
\text { belirleyen temel bir hukuki metin yoktur. } \\
\text { Ancak savunma, ticaret ve uluslararası iliş- } \\
\text { kiler dışında yereli ilgilendiren hemen he- } \\
\text { men her konuda yetki ve görevleri bulun- } \\
\text { maktadır. } \\
\text {. }\end{array}$ & $\begin{array}{l}\text { Genel yetki ilkesi hâkimdir. Yetki } \\
\text { kanunda belirtilen yetki ve görev- } \\
\text { lerle sinırl. Görevler liste yönte- } \\
\text { miyle kanunlarda belirlenmiştir. }\end{array}$ \\
\hline $\begin{array}{l}\text { Yerel } \\
\text { Yönetimlerin } \\
\text { Giderleri }\end{array}$ & $\begin{array}{l}\text { Cari harcamalar: toplam harcamaların yarı- } \\
\text { sını oluşturan sosyal harcamalar, kamusal } \\
\text { işler ve hizmetler, bina, okul ve yolların ba- } \\
\text { kımı } \\
\text { Yatırım harcamaları: eğitim binaları, sosyal } \\
\text { hizmetler, konut, kamusal işlevler ve hiz- } \\
\text { metler, eğitim, borçlar, bağışlar ve diğer } \\
\text { harcamalar ulaşım, konut ve çevresel nite- } \\
\text { likli yatırımlar }\end{array}$ & $\begin{array}{l}\text { Cari harcamalar: personel gider- } \\
\text { leri, yolluklar, hizmet alımları, tü- } \\
\text { ketim malları ve malzeme alım- } \\
\text { ları, demirbaş alımları ve diğer } \\
\text { alımlardan, } \\
\text { Yatırım harcamaları: makine, teç- } \\
\text { hizat ve taşıt alımları ile yapı, tesis } \\
\text { ve büyük onarım giderlerinden, } \\
\text { Transfer harcamaları: kurumlara } \\
\text { katılma payları ve sermaye teşkili, }\end{array}$ \\
\hline
\end{tabular}


iktisadi, sosyal ve mali transferler ve borç ödemeleri, kamulaştırma ve taşınmaz mal satın alımları,

\begin{tabular}{|c|c|c|}
\hline $\begin{array}{l}\text { Yerel } \\
\text { Yönetimlerin } \\
\text { Gelirleri }\end{array}$ & $\begin{array}{l}\text { Vergi gelirleri (council tax), yardımlar, borç- } \\
\text { lanmalar ve işletme kazançları, merkezi hü- } \\
\text { kümetin sağladığı yardımlar, }\end{array}$ & $\begin{array}{l}\text { Vergiler, Harçlar, Harcamalara } \\
\text { Katılma Payları, Genel Bütçe Ge- } \\
\text { lirlerinden Ayrılan Paylar, Bağış- } \\
\text { lar, Borçlanmalar }\end{array}$ \\
\hline $\begin{array}{l}\text { Merkezi-Yerel } \\
\text { Yönetimler İlişkisi }\end{array}$ & $\begin{array}{l}\text { Merkezi yönetimin denetimi ve yaptırımı } \\
\text { sinurlıdır. }\end{array}$ & $\begin{array}{l}\text { Merkezi yönetimin denetimi ve } \\
\text { yaptırımı vardır. }\end{array}$ \\
\hline $\begin{array}{l}\text { Yerel Yönetimlerin } \\
\text { Denetimi }\end{array}$ & $\begin{array}{l}\text { Merkezi yönetim (yasama, yürütme, yargı) } \\
\text { ve Sivil Toplum Kuruluşları }\end{array}$ & $\begin{array}{l}\text { Vesayet Denetimi, Yargısal Dene- } \\
\text { tim, Mali Denetim (Sayıştay), Etik } \\
\text { Denetim, Ombudsman Denetimi }\end{array}$ \\
\hline $\begin{array}{l}\text { Yerel Yönetimlerin } \\
\text { Özerkliği }\end{array}$ & Özerk & Kısıtlı özerklik \\
\hline $\begin{array}{l}\text { Desantralizasyon } \\
\text { Düzeyi }\end{array}$ & $\begin{array}{l}\text { Yüksek Adem-i Merkeziyetçi Yönetim An- } \\
\text { layışı }\end{array}$ & Merkeziyetçi Yönetim Anlayışı \\
\hline
\end{tabular}

Kaynak: Ökmen ve Parlak, 2015; Parlak, 2014; Gözübüyük, 1971; İnaç ve Ünal, 2006; Al, 2008; Karasu, 2004; Arıbaş, 2015; Canpolat, 1999; Department of Economic and Social Affairs, 2006; Laffin, 2008; Martin, 2011; Nadaroğlu, 1986; Şengül, 2014; Özen, 2008; Wollmann, 2012; Tortop vd., 2006; Sandford, 2016; Şengül, 2016; Özel ve Eren, 2012; Eryılmaz, 2015, Oakland, 2002.

İngiltere' de yerel yönetimler belli ve önemli işlevlere sahiptir, ancak federal sistemdeki gibi anayasal bağlamda güvence altına alınmadıkları için merkezi hükümetin bir organı veya uzantısı olarak görünmektedirler (Özel ve Eren, 2012, s.1388). Mali açıdan da merkeze bağlı olan kurumlardır (Lijphart, 2012, s.16-17). Fonksiyonları açısından (İngiltere, Kuzey İrlanda, İskoçya ve Galler) homojen değillerdir. Farklı sistemler arasında birçok fonksiyon hem alt, hem de üst düzey yönetimlere aittir (Foulkes, 1995, s.21-22). Yerel yönetimler, iki farklı şekilde yapılandırılmıştır. İskoçya, Galler ve İngiltere'nin bir kısmında tüm yerel otorite (Metropoliten veya London Boroughs) fonksiyonlarından sorumlu "tek karar meclisli" tek kademeli bir sistem varken; İngiltere'nin geri kalanında ise sorumluluğun iki meclis arasında paylaşıldığ "District" ve "County Meclisleri"'nden oluşan iki kademeli sistem bulunmaktadır (Bilge, 2007, s.3-4). Diğer taraftan 1963 yılında kurulan, 1986 yılında kaldırılan ve 1999 yılında yeniden kurulan Londra Büyükşehir Yönetimi, halk tarafından seçilen bir belediye başkanı ve büyükşehir meclisine sahip farklı bir yerel birim olarak hizmet vermektedir (Kösecik, 2000, s.75). İskoçya, Galler ve Kuzey İrlanda'da İngiltere'deki yerel yönetimlere benzer bir yap1lanma bulunmaktadır. 
İngiltere'de Türkiye'de olduğu gibi merkezi yönetime bağll, il ve ilçelerden oluşan bir taşra örgütlenmesi ve valilik gibi bir idari vesayet kurumu mevcut olmadığ 1 için diğer ülkelerde taşra örgütlerinin yaptığ1 işin önemli bir kısmı yerel yönetimlerce gerçekleştirilmektedir (Karasu, 2004, s.108). Sadece belli bazı görevler tüzel kişiliğe sahip, idari ve mali olarak özerk birimlerce yerine getirilmektedir. Örneğin sağlık hizmeti, sosyal yardım ve istihdam hizmetleri, denetimli serbestlik ve cezaevi hizmetleri gibi bazı hizmetler, yasa ile kurulan ve bir bakanlığa bağlı olan Bölge Yönetimi, Bölge Kalkınma Ajansı ve Bölgesel kurullar gibi kuruluşlar tarafından yerine getirilmektedir (Arıbaş, 2015, s.5; Karasu, 2004, s.109; Ökmen ve Parlak, 2015, s.60). Çevre Ajansı, Sanat Konseyi, Beceri Fonlama Ajansı ve Eğitim Fonu Ajansı gibi hükümet tarafından kurulan fon sağlayıcılar da bu kapsamda hizmet vermektedir (Sandford, 2016, s.6). Günümüzde sayısı 408'i bulan bu tür örgütlemelerin (GOV.UK, 2019), Thatcher Hükümeti tarafından yerel yönetimleri zayıflatmak amaciyla kurulduğu belirtilmektedir (Wollmann, 2012, s.62). Merkez ve yerel arasındaki ilişki, Başbakan Yardımcısı, Eğitim Bakanlığı, Çalışma ve Emeklilik Bakanlığı ve Sağlık Bakanlığı aracılığıyla gerçekleşmektedir (Department of Economic ve Social Affairs, 2006, s.8).

Genel olarak İngiltere'de ilk kademede yer alan ve il statüsünde bulunan yerel yönetim birimi "County"ler, coğrafi alanda belli sınırlara sahip bir ili değil, yerel yönetim anlamında ili ifade etmektedir (Kavruk, 2002, s.112). Eski bir geleneğe sahip ve belli dönemlerde artış veya azalış gösteren Countyler, "Council" adı verilen ve doğrudan halk tarafından seçilen bir karar alma organına sahiptir (Ökmen ve Parlak, 2015, s.286). Bununla birlikte, meclis kendi üyeleri arasından "mayor" adı verilen tarafsız bir başkan seçmektedir. Ayrıca meclislere bağlı olarak faaliyet gösteren ve yerel yönetim için güç olarak kabul edilen polis, itfaiye ve acil durum, ulaşım ve kalkınma departmanları gibi uzman alt kurullar da bulunmaktadır (Stewart, 2014:841). County'lerden sonra gelen District (bölge)'lerin District Council (bölge meclisleri) seklinde meclisleri; mayor denilen seçilmiş başkanları, metropoliten alanlarda tek kademeli yerel hizmetlerden doğrudan sorumlu birimler ve metropoliten olmayan alanlarda ise il sisteminin ikinci kademesi olarak yapılandırılmışlardır (Kavruk, 2002, s.112). Kökenleri çok eskiye dayanan üçüncü ve son kademe yönetimleri olan Parish'ler, günümüz köy ve mahalle yapılanması şeklinde yalnızca kırsal alanda değil, mahalleler aracılığıyla da kentlerde varlığını sürdürmektedirler (Güler, 2013, s.78-79). Nüfusu 200'e kadar olan Parishler'de 
doğrudan halkın katılımı, 200'ü geçen köy ve kasabalarda ise meclis faaliyeti zorunlu olmaktadır (Ökmen ve Parlak, 2015, s.287). Council olmayan yerlerde ise küçük halk toplantıları yapılarak yerel sorunlara çözüm bulunmaya çalışılmaktadır (Kavruk, 2002, s.113). Günümüzde Londra Anakent Belediyesi'nde ve sayıları 15'i bulan yerel yönetimler dışında tüm belediye başkanları, meclis tarafindan seçilmektedir (Wollmann, 2012, s.48).

Türkiye'de ise yerel yönetimler, yerinden yönetim ilkesi çerçevesinde Anayasa'nın 123. ve 127. maddesi ile düzenlenmiştir. 123. madde ile idarenin bütünlüğü ilkesi vurgulanmakta, idarenin hem merkezden yönetim hem de yerinden yönetim esaslarına dayandığ ifade edilmektedir. 127. madde de ise yerel yönetimlerin kuruluş esasları, seçimler, idari vesayetin hangi hallerde kullanılacağı anlatılmaktadır. Yerel yönetim birimleri, belediye, il özel idaresi ve köy olmak üzere üç kategoriye ayrılmıştır. En küçük yerel yönetim birimi olan köylerin ihtiyaçları, çoğunlukla merkezi hükümet ya da il özel idarelerince karşılanmaktadır. Mahalle ise, belediye seviyesinde yerel yönetimin en küçük birimi olarak kabul edilmektedir. Belediyeler, il ve ilçe merkezlerinde zorunlu, beldelerde ise nüfusu 5.000 ve üzeri olan yerlerde kurulabilmektedir. İl Özel İdareleri, büyükşehir olan iller dışında her ilde, kırsal alanların ihtiyaçlarının karşılanması için il sınırları içinde belediyelerin sorumlu olmadığı alanlardan işlev görmektedir.

Aslında Köy ve İl Özel İdareleri var olmakla beraber, en önemli yerel yönetim birimi belediyelerdir. Türkiye'de belediyeler, statü olarak değişik kategorilerde yer alır. En önemli ayrım büyükşehir belediyeleri ve diğer belediyeler arasındadır. Bunun dışındaki farklılıklar daha çok idari statüden kaynaklanmaktadır. 5393 ve 5216 sayılı Yasalara göre, hem büyükşehir belediyesi hem de diğer belediyelerdeki yönetimlerin Belediye Meclisi, Belediye Encümeni ve Belediye Başkanı olmak üzere üç temel organı vardır ancak, bu organların seçimi, temsilin işlevselliği ve organların oluşum biçimi, çoğu kez seçkinci bir yapıya sahip olduğu ve bazı temsil sorunlarının yaşandığı ifade edilmektedir (Bulut ve Taniyıc1, 2008, s.174).

\section{Yürüttükleri Hizmetler Açısından Karşılaştırılma}

İngiltere'de yerel yönetimlerin fonksiyonlarının bir ülkeden diğerine veya kent bölgelerinde farklılık göstermesi ve iki düzeyli sistem içinde birçok fonksiyonun hem alt, hem de üst düzey yönetimleri ilgilendirmesi nedeniyle yerel 
yönetimlerin görevleri ile ilgili bir sınıflandırma yapmak oldukça güçtür (Türkoğlu, 2009, s.29; İnaç ve Ünal, 2006, s.131). Türkiye' de ise, köy hizmetlerinin genellikle il ve ilçe mülki amirliklerince yapıldığı, büyükşehir olmayan yerlerde il özel yönetimlerinin hizmetleri merkez-yerel işbirliği çerçevesinde yapılmaktadır. Belediye hizmetleri de belediye mevzuatı ve anayasa açısından "genellik" ilkesine göre kamu hizmetlerini yerine getirmektedirler. Her ne kadar merkezi yönetimin vesayeti etkin bir faktör olarak (Nadaroğlu, 1986, s.81) görülse de belediyelerin yerel halkın ihtiyaçlarını önemli ölçüde giderebildiği söylenebilir. Bu bağlamda belediyelerin görevli oldukları hizmet alanları, Belediye Kanunu ve diğer ek mevzuatlarda ayrı şekilde belirtilmiştir.

\section{Koruyucu Hizmetler}

Koruyucu hizmetler polis hizmetleri, itfaiye ve vatandaşın korunması ile ilgili hizmetleri kapsamaktadır. Koruyucu hizmetler konusunda İngiltere ve Türkiye yerel yönetimleri arasında farklılıklar bulunmaktadır. Tarihsel olarak İngiltere, Galler ve İskoçya polis güçleri, merkeze bağlı olduğu dönemlerde bile milli teşkilattan ziyade bir yerel birim olarak hizmet vermişlerdir (Öcal, 2001, s.49). İngiltere'de merkezi bir polis teşkilatı olmamasına rağmen Londra polisi dışında polis hizmetleri 18. yüzyıldan beri yerel yönetimler tarafından sürdürülmekte, 1946 yılında çıkarılan polis yasası ile merkezi yönetim tarafından finanse edilmekte ve İçişleri Bakanlığı tarafından denetlenmektedir (Karasu, 2004, s.116). Sadece il, bölge ve metropoliten yerel yönetim birimi meclisi tarafından yürütülen bu görev, üçte ikisi meclis üyelerinden üçte biri de yargiçlardan oluşan polis komiteleri tarafından yürütülmektedir (Canpolat, 1999, s.328).

Türkiye'de polis hizmetleri İçişleri Bakanlığı'na bağlı Emniyet Genel Müdürlüğü tarafından yürütülmektedir. Belediyelere bağlı olarak belediye sınırları içerisinde kamusal bazı hizmetlerin yürütülmesi ve kontrolünü sağlayan zabıta, Büyükşehir belediyelerinde trafik zabıtası, özel kolluk kuvveti görevlisi olarak hizmet vermektedir. 5216 sayılı Büyükşehir Belediyeleri Yasası'nda, "güvenlik" ibaresi bulunmamasına rağmen 5393 sayılı Kanunun 14. maddesinde zabita hizmetleri, belediyelerin "hizmet yüklenmeleri" arasında sayılmaktadır. "Gelecek yıllara yaygın hizmet yüklenmeleri" başlı̆̆ını taşıyan 67. maddesi güvenlik hizmet alımının yasal dayanağını oluşturmaktadır. 
5393 sayılı Belediye Yasanın 14. maddesinde, belediyelerin zabıta hizmetlerini "yapacağı veya yaptıracağı" belirtilmiş ve 51. maddede bu hizmetlerin asli ve sürekli görev niteliğindeki zabita hizmetleri ile kamu gücü kullanmayı gerektirmeyen zabıta destek hizmetleri şeklinde yapılacağı belirtilmiştir ( $\mathrm{Fl}_{1}$ rat, 2008, s.221).

\section{Çevre ve Altyapı Hizmetleri}

İngiltere'de çevre sağlığının korunması, trafik ve ulaştırma, sivil savunma, konut hizmetleri ve genel imar plânlarının hazırlanması ile ilgili görevler il, bölge ve metropoliten meclisleri arasında bölüşülmüştür (Canpolat, 1999, s.328-329). Hıfzıssıhha ve gida kontrolü, daire, dükkân ve fabrikalardaki sağlık şartlarının yerine getirilmesinin kontrolü, bulaşıcı hastalıklardan korunma, çöp toplama ve yok etme hizmetleri, hayvan hastalıkları, mezbahalar ve halka açık tuvalet yapımı, hava kirliliğinin önlenmesi, patikalar veya yaya yollarının yapılması, karayolları gibi hizmetler District ve Metropoliten District Meclislerinin sorumluluğunda bulunmaktadır (İnaç ve Ünal, 2006, s.132). Otoyol yapımı, bakımı ve onarımı, yol güvenliği, trafik düzenlemelerinin yapılması ve kontrolü, konut yapımı, park yerleri cadde ve sokakların aydınlatılması, çöplerin imhası hizmetleri County ve Metropoliten Districtler tarafından yerine getirilip ve kontrol edilmektedir. Genel imar planlarının hazırlanması County Meclisleri tarafından, bu planların uygulanması ise District ve Metropoliten Districtler tarafindan yerine getirilmektedir (Okutan, 2009, s.98). 1973 yılında çıkarılan su kanunu ile yerel idareler yerine suyla ilgili her türlü görevi yapmak üzere bölgesel su otoriteleri kurulmuş ve daha sonra bu bölgelerdeki suyla ilgili hizmetler 1980 yılındaki Konut Yasası ile özelleştirilmiştir (Yamaç, 2014, s.10; Canpolat, 1999, s.328).

Türkiye'de yerel yönetimler, çevre kirliliğine yol açabilecek bütün konularda denetim ve hizmet görevlerini yerine getirmektedirler (Çoban ve Kılıç, 2009, s.120). İl özel idarelerinin çevre ile ilgili görevleri il içinde ve belediye sınırları dışında olmak üzere iki şekilde gerçekleşmektedir. İl sınırları içinde, başta sağlık, gençlik ve spor, sanayi ve ticaret, kültür, sanat, turizm, sosyal hizmet ve yardımlar, yoksullara mikro kredi verilmesi, çocuk yuvaları ve yetiştirme yurtlanı, ilk ve orta öğretim kurumlarının arsa temini, binaların yapım, bakım ve onarımı, belediye sınırları il sınırı olan büyükşehir belediyeleri hariç ilin çevre düzeni planı, bayındırlık ve iskân, tarım, toprağın korunması, 
erozyonun önlenmesi gelmektedir (Erdem, 2015, s.23). Belediye sınırları d1şında ise imar işleri, yol, su ve kanalizasyon yapılması, katı atık depolama ve yok etme faaliyetleri, çevre acil yardım ve kurtarma, orman köylerinin desteklenmesi, ağaçlandırma park ve bahçe tesisine ilişkin hizmetleri yapar (Şengül, 2014:55). 5393 sayılı Belediye Kanunu'n 14 ve 15. maddelerinde belediyelerin mahallî müşterek nitelikte olmak şartıyla coğrafî ve kent bilgi sistemleri, imar işleri, su ve kanalizasyon, ulaşım gibi kentsel alt yapı, çevre ve çevre sağlığı, temizlik, şehir içi trafik, defin ve mezarlıklar, ağaçlandırma, park ve yeşil alanlar, konut hizmetleri, kaynak suları, katı atık bertarafı ve bunlar için gerekli alt yapı ve tesisleri sağlama hizmeti sunmakla görevlendirildikleri görülmektedir.

\section{Ĕ̆itim, Sağhk ve Sosyal Hizmetler}

İngiltere'de 1902 ve 1944 tarihli eğitim yasalarıla yerel yönetimler ve bağlı bölge meclisleri, merkezi idarenin ulusal eğitim planlarına ve denetimine tabi olarak, yaygin eğitimin yerine getirilmesi konusunda yetkili kılınmışlardı (Karasu, 2004, s.116). Ancak Thatcher Hükümeti, tüm hizmet alanlarında olduğu gibi eğitim hizmetlerinde de merkezi yönetimin ağırlığını arttırmıştır. 1988 ve 1993 eğitim yasalarıyla eğitim kurumlarının denetimi, Eğitim ve Beceri Geliştirme Bakanlığı'na bağlanarak merkezin eğitim üzerindeki etkisi arttırıldı (Wollmann, 2012, s.52). Yerel yönetimlerin görev alanlarındaki bir kısım görevler merkezi yönetime bağlı bölgesel özerk kuruluşlara, alt kademelere, gönüllü kuruluşlara devredilirken bir kısmı da tamamen özelleştirilmiştir. Buna rağmen eğitim, sağlık ve sosyal hizmetler alanı gibi birçok kamu hizmeti yerel yönetimler tarafından gördürülmektedir (Oakland, 2002, s.66). Eğitim, hem harcama hem de düzenli olarak halka ulaşma açısından yerel yönetim hizmetleri içerisinde önemli bir paya sahiptir (Okutan, 2009, s.97). 1974'e kadar yerel meclisler tarafından yürütülen sağlık hizmetleri, bu tarihten sonra bu hizmetler yerel yönetimler ile ilişkisi olmayan ve ülke çapında bölgesel mahiyette kurulan özerk yapıdaki sağlık otoritelerine devredilmiştir (İnaç ve Ünal, 2006, s.133). Ayrıca Ulusal Sağlık İdaresi, sağlık alanında merkezi bir örgütlenme olarak görev yapmaktadır (GOV.UK, 2019). Sosyal hizmetler kapsamında kimsesizlere yer temini, gençlerin ve özürlülerin mesleki eğitim konuları yerel yönetimlerin görev alanı dâhilinde bulunmaktadır (Okutan, 2009, s.97). 
Türkiye'de 5393 sayılı Belediye Yasası'nın 14. Maddesine göre belediyeler, yerel düzeyde ve müşterek nitelikte olmak koşuluyla, devlete ait her derecedeki okul binalarının inşaatı ile bakım ve onarımını yapabilir veya yaptırabilmekte, her türlü araç, gereç ve malzeme ihtiyaçlarını karşılayabilmektedir. Söz konusu yasa, belediyelerin sağlıkla ilgili her türlü tesisi açabileceğini ve işletebileceğini ve gida bankacilı̆̆ yapabileceğini ifade etmektedir. Yine 14. Maddenin devaminda belediye hizmetlerinin, vatandaşlara en yakın yerlerde ve en uygun yöntemlerle sunulacağını ve hizmet sunumunda engelli, yaşlı, düşkün ve dar gelirlilerin durumuna uygun yöntemler seçileceği belirtilmektedir. 5216 sayılı Büyükşehir Belediye Kanunu'nun 7(n). Maddesinde büyükşehir belediyeleri ve bağlı ilçe belediyelerinin eğitim ve kültür hizmetleri ile yaygin mesleki eğitim hizmetleri konusunda benzer yetki ve sorumluluklara sahip olduğu belirtilmektedir.

5302 sayılı İl Özel İdaresi Kanunu'n 6. maddesinde göre ise il özel idareleri, ilköğretim ve ortaöğretim kurumlarına arsa temini, bina yapımı, bakım ve onarımları, yetiştirme yurtları kurma ve işletme ile görevli ve yetkili olduğu belirtilmiştir. Ayrıca bakanlıklar ile diğer kamu kurum ve kuruluşları; eğitim yatırımlarına ilişkin olarak kendi bütçelerinde bulunan kaynakları il özel idarelerine aktararak hizmetleri gerçekleştirebilirler.

\section{Mali ve Denetim Yapılarn Açısından Karşılaştırma}

Yerel yönetimlerin her birinin kendi yönetim şekli ve çerçevesi içinde çalıştığ İngiltere'de, yerel yönetimler tamamen özerk kuruluşlar olduğu için üniter devlet yapılarında sıklıkla göremediğimiz vergi toplama dâhil genelde merkezi otoritelerin yaptığı birçok mali işlevi yerine getirmektedirler (Kazancı, 1983, s.43). Buna rağmen yerel bütçelerin işlemleri, yapıları ve kayıtları yönünden uygulanan tek bir şekil yoktur. Ancak yerel yönetimlerin bütçelerin hazırlanması, harcamaları, mali müdahale düzeyi konusunda hukuki düzenlemeler getirilerek yerel yönetimlerin mali performansları yükseltilmiştir (Ökmen ve Parlak, 2015, s.63-69). Bütçe hazırlanması ve onaylanmasına ilişkin işlemler, muhtarlıklar dışında Türkiye' deki uygulamayla benzerlik göstermektedir. Diğer yandan merkezi yönetim, performans yönetimi ve finansal kontroller ile yerel yönetimleri kendine bağlamıştır (Martin, 2011, s.69; Wollmann, 2012, s.53). Özellikle son on beş yıldan beri İngiliz yerel yönetimi, 
performans ve finansal denetimlere sıkı sıkıya bağlı kalmakta ve buna teşvik edilmektedir (Martin, 2011, s.75-78).

İngiltere'de yerel idare gelirleri vergiler, yardımlar, paylar, borçlanma ve diğer gelirlerden (AB Fonları vb.) oluşmaktadır. Yerel idarelerin kendi adlarına alabildikleri en önemli vergi "council tax" denilen vergidir (Tortop, 1994, s.48). County'ler tarafından toplanan gelirler, bağlı beldelerin nüfusuna göre dağıtılmaktadır (Ökmen ve Parlak, 2015, s.290-291). Yerel yönetimler ayrıca bazı durumlarda borçlanmaya da gidebilmektedirler. 1990'li yıllardan 2004 yılına kadar proje bazlı borçlanma yapabilirlerken, daha sonra yapılan yeni düzenlemelerle belirli bir limit dâhilinde borçlanma yetkisi kendilerine tanınmıştır (Türkoğlu, 2009, s.29-31). Ayrıca yerel yönetimler gelir sıkıntısı çektiklerinde merkezi yönetim tarafından "grants" denilen yardımlar da yapılmaktadır (Ökmen ve Parlak, 2015, s.63-69). Yerel yönetimler, oldukça geniş bir gelir kaynağına sahip olmasına karşın gelirlerin kullanılmasında oldukça sıkı bir merkezi denetim bulunmaktadır (Karasu, 2004, s.119). Yasama, yürütme, yargı dışında Sivil Toplum Kuruluşları da denetim mekanizması olarak görev yapmaktadır (Parlak, 2014, s.33-34). Buna rağmen İngiltere'de yerel yönetimler, toplam kamu harcamalarının \% 25'ini gerçekleştirmektedir. Bu oranın büyük bir kısmı devlet memuru olmayan personelin yarısından fazlasına sahip olan belediyelerin personel gideri olarak gerçekleşmektedir (Wollmann, 2012, s.48). Bunun yanında bütçelerinin önemli bir kısmını da sosyal harcamalara ayırmaktadırlar (Yamaç, 2014, s.12). 1997-2017 yılları arasında İşçi Partisi hükümetleriyle ile sosyal harcamaların harcama çevresi arttırılmıştır. 2010 yılında kurulan koalisyon hükümeti, politik ve ekonomik iklimde ciddi bir değişiklik göstererek yerel yönetimler alanında mali ve finansal özerklik sağlanacağına ilişkin vaatler vermiş ve bu yönde çalışmalar gerçekleştirmeye çalışmıştır (Wilson and Game 2011, s.395). Yerel yönetimlerin harcamalarını denetleyen kurum ise Çevre Bakanlığıdır (Canpolat, 1999, s.334). Çevre Bakanlığı özellikle yatırım harcamaları ile ilgili konularda denetleme yapmaktadır (Ökmen ve Parlak, 2015, s.292).

Türkiye'de yerel yönetimlerin kendine özgü gelir kaynakları olsa da bunların oranı düşüktür. Dolayısıyla yerel hizmetlerin finansmanının önemli bir bölümü merkezi yönetimler tarafından karşılanmaktadır. 5393 sayılı Kanunun 59. maddesinde yerel yönetimlerin gelirleri genel olarak "vergi gelirleri", "teşebbüs ve mülkiyet gelirleri", "alınan bağış ve yardımlar ile özel gelirler", "faizler, paylar ve cezalar", "sermaye gelirleri" ve "alacaklardan tahsilât" 
toplamından oluşmaktadır. 5779 sayılı Kanuna göre genel bütçe vergi gelirlerinin yüzde 2,85'i büyükşehir sınırları dışında kalan belediyelere, yüzde 2,5'i büyükşehir ilçe belediyelerine ve yüzde 1,15'i il özel idarelerine ayrılmaktadır. Büyükşehir belediyeleri ise büyükşehir sınırları içinde toplanan vergilerin yüzde 5'ini almaktadır (Toksöz vd., 2009, s.55).

Belediye Kanunu'nda ve değişik kanunlarda belediyeler, kendi sorumluluk alanındaki görevleri yerine getirebilmek için harcamalarda bulunmak zorundadır. Belediyelerin giderleri, cari harcamalar, yatırım harcamaları ve transfer harcamalarından oluşmaktadır. Belediyelerin (m.60), bina, tesis, araç ve malzemelerinin temini, yapımı, bakımı ve onarımı için yapılan giderler, alt yapı, yapım, onarım ve bakım giderleri, belediyenin personeline ve seçilmiş organlarının üyelerine yapılan ödemeler, avukatlık, danışmanlık ve denetim giderleri, mezarlıklara ilişkin giderler, faiz, borçlanma, diğer ödemeler ile sigorta giderleri, sosyal hizmet ve yardımlar, dava giderleri, tören, ağırlama ve tanıtım giderleri, ortak hizmet ve proje giderleri, görev ve hizmetlerin yürütülmesi için yapılan diğer giderler ve imar düzenleme giderleri bulunmaktadır (Türkoğlu, 2009, s.115-116).

5018 sayılı Kamu Malî Yönetimi ve Kontrol Kanunu'na göre belediyeler, il özel idareleri ve bağlı kuruluş ve işletmelerin iş ve işlemlerinin hukuka uygunluğu kapsayan iç ve dış denetimi yapılmasını zorunlu kılmaktadır. Ayrıca malî işlemler dişında kalan diğer idarî işlemler, idarenin bütünlüğüne, kalkınma plânı ve stratejilerine uygunluğu açısından denetimi İçişleri Bakanlığı, vali veya görevlendireceği personel tarafından yapılmaktadır. 5018 sayılı kanunla gelen yeni düzenlemeye göre, belediyelerde belediye başkanı, il özel idarelerinde de valiler yapılan tüm harcamalardan kendi meclislerine hesap verme yükümlülügünndedirler. Tüm il genel meclisleri, nüfusu 10.000'in üzerindeki belediyelerin meclisleri, il merkezi olan belediyeler ve ilçe belediyeleri her senenin başında meclis üyelerinden oluşturulan ve 3-5 üye arasında değişen üye sayısıyla bir denetim komisyonu kurmakla yükümlüdür (Toksöz vd., 2009, s.55-56). Dış denetim halen Sayıştay tarafından yapılarak rapor edilmekte ve dış denetim genel değerlendirme raporunu her yıl Eylül ayı içerisinde Türkiye Büyük Millet Meclisi'ne sunmaktadır. 


\section{Sonuç ve Tartışma}

Bugün dünyanın hemen hemen tüm demokratik ülkelerinde yerel yönetimlerin merkezi yönetimlere göre daha etkin bir pozisyonda olduğu söylenebilir. Özellikle kamu hizmetlerinin etkin sunumu, halka yakınlı, kamu kaynaklarının daha verimli kullanımı ve kamu harcamalarının daha dengeli yapılması, hepsinden önemlisi demokratik değerlerin hayata geçirilmesi gibi birçok konuda yerel yönetimlerin, genel yönetim yapısı içinde önemini ortaya koymaktadır. Diğer taraftan nüfus artışı, coğrafi yapı, tarihsel birikim, bilimsel ve teknolojideki gelişmelere bağlı olarak akıllı kent ve yapay zekâ uygulamaları, küreselleşme, yerelleşme, yönetişim gibi süreçlere bağlı olarak hizmet çoğulculuğu, hizmette etkinlik ve verimliliği esas alan yeni yaklaşımların ortaya çıkması, yerel yönetimlerin önemini arttırmış ve onları yeni yönetim modelleri arayışına sevk etmiştir. Tarihsel süreç içerisinde sosyo-kültürel olarak farklı, ancak devlet yapıları açısından benzer olan İngiltere ve Türkiye'de yerel yönetimlerin gelişim süreçleri ve bugünkü mevcut konumuna gelmesi de bu arayışların sonucunda gerçekleşmiştir. İngiltere'de, Anglo Sakson anlayışına dayanan yerel yönetimlerin bugünkü durumu, köklü yerel yönetim geleneklerine ve tarihsel birikimine dayandığı görülmektedir. Halkın ihtiyaçlarını karşılayan en uygun ve etkili yerel yönetim sistemini hayata geçirmek amacıyla Türkiye'deki yerel yönetim modellerinden farkı, farklı bölge ve kentlerde çeşitli yerel yönetim tarzlarını ortaya çıkartması ve bunları sürdürülebilir kılmasıdır. Bu durum, İngiliz yerel yönetim sisteminin üç önemli özelliğini ortaya koymaktadır. Bunlar; yerel yönetim birimlerinin nicelik ve nitelik olarak değişikliğe açık olması, halka hizmet noktasında bütüncül olmaktan uzaklaşmayı bile göze alması ve son olarak yerel yönetim yapılarının başka toplumlarda uygulanan yerel yönetim yapıları örnek alınmadan süreç içinde ortaya çıkan ihtiyaçlara göre biçimlenmesidir. Bu özellikler, yerel yönetimlerin halka daha yakın olmasını, halkın yönetime doğrudan katılabilmesini, sorunların zamanında çözümlenebilmesini ve halkın karar mekanizmalarında daha etkili olabilmesini sağlamıştır.

Türkiye'de ise, 2000'li yıllara kadar daha çok merkeze bağlı veya kaybolan merkezin gücünü yeniden tesisi bağlamında ele alındığı söylenebilir. Nitekim Tanzimat'a kadar hatta Tanzimat sonrası da bu yaklaşım açıkça görülmüştür. Diğer bir ifade ile Türkiye'de yerel yönetimlere ilişkin gelişmeler, 
daha çok merkez-yerel tartı̧̧maları bağlamında ele alınmıştır. Nitekim Osmanlı Devleti'nin son dönemlerinde yeniden yapılandırma çalışmalarında, yerel yönetimlerin gelişmesinden ziyade kaybolan merkezi otoritenin tekrar tesisi nasıl yapılır arayışları şeklinde olmuştur. Cumhuriyet döneminde de benzer izler görülmektedir. Özellikle 1980 sonrası, küreselleşme ve yerelleşme tartışmaları ve bunların merkeziyetçi yapı üzerinde oluşturduğu endişe ve korkular, yerel yönetimler alanında devletin temel birlik ve bütünlügünü koruma düşüncesini ön plana çıarmıştır. Bununla beraber, $\mathrm{AB}$ üyelik süreci ve küreselleşmeye-yerelleşme bağlamında yerel yönetimlerin güçlendirilmesi gerektiğine ilişkin eğilim, merkezin gücünü test etmediği sürece olumlu karşılanmıştır.

İngiliz yerel yönetimleri, savunma, ticaret ve uluslararası ilişkiler dışında yereli ilgilendiren hemen hemen her konuda yetkili kılınmasına rağmen, özellikle 1980 sonrası etkin, verimli, şeffaf ve hesap verebilir bir yönetim anlayışının yerelde uygulanması, mali açıdan hem denetimi arttırmış hem de özerkliği sınırlandırmıştır. Mali konularda merkezi yönetime bağımlılıkları nedeni ile yetki ve sorumluluklarını çok sayıda aktörle paylaşmak durumunda kalmış ve yerelde etkili birer otorite haline gelmeleri engellenmiştir. $\mathrm{Bu}$ da, yerel yönetimlerin sadece kendilerine ayrilan alanlarda kural koyma ve iş yapabilme konusunda özerk olmasını doğurmuştur. Her ne kadar bölgeselleşme yönünde atılan adımlarla kurulan yerel meclislerin varlı̆̆ı ortaya çıkmış olsa da, özellikle 2000'li yıllardan sonra performans yönetimi ve finansal kontrollerde, hükümetlerin tavrının yerelleşme değil merkezileşme yönünde olduğunu görülmektedir. Yerel yönetimlerin gelirlerinin çok büyük bir kısmının devlet yardımları ile karşılanması, bu yardımlarının birçoğunun özel amaçlı olması ve yerel yönetimlere harcama serbestliği verilmemesi, denetim araçlarının fazla olması gibi birçok konu eleştirilmektedir. Son yıllarda oluşan koalisyon hükümetleri, yerel yönetimleri daha çok güçlendireceklerine ve merkezin denetiminden uzaklaştıracaklarına ilişkin vaatlerde bulundukları da görülmektedir.

Türkiye'de ise, özellikle 2000'li yıllardan sonra yerel yönetimler alanında reformlar gerçekleştirilmiş ve vesayet denetimi, hukuka uygunluk denetimi bağlamında hafifletilmiştir. Bununla beraber, idari ve mali açıdan vesayet makamlarının sınırlı denetimi ve Sayıştay gibi kurumların genel denetimi devam etmektedir. Yerel hizmetlerin daha etkin yapılabilmesi ve mali özerkliğin sağlanabilmesi için yerel yönetimlerinin kendi öz gelirlerinin artırılması 
ve merkezi yönetime bağımlılığının giderilmesi gerekmektedir. İngiltere'deki gibi farklı yerel yönetim modellemelerinin geliştirilmesi demokrasi ve katılım açısından önemli gelişme sağlayacaktır. Özellikle 2004 ve 2005 sonrası çıkarılan yerel yönetim yasaları, büyük şehir yönetim modellerine ilişkin arayışlar, akıllı kent uygulamaları konusunda model geliştirme çabaları, Türkiye'de yerel yönetimlerin daha etkin hale getirilmesi çabası olarak görülebilir. Bütün bunlara rağmen, hala Türkiye'de yerel yönetimler üzerinde merkezi yönetimin etkisinin çok olduğunu söylemek mümkündür. Dolayısıyla Türkiye'de merkezi yönetime bağımlılığı daha önde görülen bir yerel yönetim varken İngiltere' de daha özerk ve demokratikleşme kültürü geleneğinin bir yansıması olarak şekillenen bir yerel yönetim olduğu söylenebilir. Ancak yerel yönetimlerin yasal ve anayasal güvencelerinin olmaması hükümetlerin kontrolsüzce müdahalelerine maruz bıraktığını da ifade etmek gerekir. Bu açıdan sebepleri farklı da olsa yerel yönetimler açısından her iki ülkede de yetki-görev paylaşımı, gelir paylaşımı ve idari denetim konularında hala dezavantajlar olduğu görülmektedir. 


\title{
EXTENDED ABSTRACT
}

\section{A Comparative Analysis Of Local Administration: The Samples in the UK and Turkey}

\author{
Yakup Bulut - Muzaffer Bimay \\ Gaziantep University, Batman University
}

This study aiming at comparing local government systems between Turkey and the UK that have long-established state traditions in spite of different social and cultural structures, deals with different and similar aspects, centerlocal relations, administrative, financial, control and autonomy dimensions, and decentralized levels by comparing the local government systems implemented in both countries in terms of their structure, duties and powers. Especially in today's world where centralization and localization discussions are common, what are the legal and constitutional regulations regarding local governments in the context of restructuring in both countries, how effective local governments are in implementation, the course of authority, resource and expenditure levels and what kind of contribution they provide for the democratization of local government units.

Continuously changing central-local relations depending on the political processes from Ancient Greek and Roman cities to the present, increased the importance of local governments and led countries to seek new management models after the Industrial Revolution, the increasing population in cities, developments in mass media, liberal approaches based on efficiency and efficiency in service, service pluralism that emerged due to processes such as globalization, localization and governance. Being different within socio-cultural context in historical process but similar in terms of state structures, England and Turkey, reached to present the current position of their local governments as a result of this quest.

Local governments in England emerged during the Anglo Saxon period and took a form in the 11th century, similar to the structure practiced today. Therefore, the current situation of local governments is based on long-established local administration traditions and historical background. Thanks to this long-established tradition, British local governments have developed 
various styles of local governance in different regions and cities in order to implement the most appropriate and effective local government system that meets the needs of the people and tried to make them sustainable. On the other hand, British local government units are open to change in terms of quantity and quality, taking even the risk of moving away from being holistic in terms of service to the public, and shaping local government structures according to the needs that arise in the process, without taking local government structures applied in other societies as an example, It has revealed a local government understanding specific to England. In Turkey, there is a tradition of local government with a two century background. The central and local regulations that started with the Tanzimat reform era in the last periods of the Ottoman Empire also continued with the Constitutional period and the constitutional process emerged in the Republic Period. In spite of different aspects from the process in Great Britain, regulations on local governments in Turkey, especially after 2000, shows that they prioritize efficiency in public services and resembles centralization to a certain extent. However, considering the reforms made, it can be said that local governments are increasingly becoming more prominent in terms of public service delivery, even if considered in the context of central-local discussions. Indeed,in the World dominated by globalization and neo-liberal politics, since 1980s, new trends have emerged on local governments both in the UK and Turkey, With the effect of public and private areas shifting to localization and governance.

Although British local governments were authorized in almost all matters concerning the local, except for defense, trade and international relations, the local implementation of an effective, efficient, transparent and accountable administration approach after 1980 both increased financial control and limited autonomy. In spite of the existence of local councils established with the steps taken towards regionalization, especially after the 2000s, in performance management and financial controls, the attitude of governments was seen in the direction of centralization rather than decentralization. Depending on the globalization and neo-liberal policies in the 1980s, the EU accession process and the Globalization and decentralization context after the 2000s and the growing trend on the need to strengthen local governments, local government reforms have been implemented in Turkey. However, the limited supervision of the guardianship authorities in terms of administrative and financial aspects and the general supervision of institutions such as the 
Court of Accounts showed that the aforementioned regulations did not go beyond emphasizing the idea of protecting the basic unity and integrity of the state. Although the local government laws enacted in the years, 2004, 2005 and 2012 and the quests for the big city management model are considered to be as efforts to make local governments more effective, local government in Turkey maintains its existence as dependent on the central administration in Turkey. It can be said that local governments are still under the custody of the central government, especially despite the fact that the tutelage practice has been brought to the dimension of compliance with the law. Although the developments after the 1980s are considered as a shift to centralization to a certain extent, in the UK, a local administration style that is shaped as a reflection of the tradition of a more autonomous and democratization culture with a long-established tradition and unique characteristics in general are still prevalent. Nevertheless, it should be stated that the lack of legal and constitutional guarantees of local governments exposes governments to uncontrolled intervention. Although the reasons are different in this respect, it can be said that there are still disadvantages in terms of authority-task sharing, revenue sharing and administrative control in both countries. In this context, after briefly emphasizing how local government systems have had a meaning within the present administrative systems, it is argued how much local governments have developed and ultimately how the local governments emerged both in Turkey and the UK. As a result, local governments need to increase their own revenues and eliminate their dependence on the central government in order to provide more effective local services and ensure financial autonomy. In addition, in Turkey, the development of different local authorities in England, such as modeling will provide important advances in terms of democracy and participation.

\section{Kaynakça / References}

$\mathrm{Al}, \mathrm{H}$. (2008). Yeni kamu yönetimi: Ülke deneyimleri. İstanbul: Değişim Yayınları.

Arıbaş, N. N. (2015). İngiltere ve Fransa'da merkez-yerel ilişkilerini yerellik (subsidiarity) ilkesi üzerinden karşılaştırmak. Akademik Yaklaşımlar Dergisi, 6(1), 1-17.

Ateş H.ve Demirel, D. (2014). Üçüncü yol ve İngiltere'de Blair dönemi kamu reformları. Amme İdare Dergisi, 47(3), 1-18. 
Aydınlı, H. İ. (2004). Sosyo-Ekonomik dönüşüm sürecinde belediyeler. Ankara: Nobel Yayınları.

Ayhan, U. (2008). Amerika Birleşik Devletlerinde yerel yönetimler. Sayıştay Dergisi, 103-120.

Bilge, S. (2007). İngiliz Yerel yönetimlerinde performans ölçüm uygulamaları. Eskişehir Osman Gazi Üniversitesi Sosyal Bilimler Dergisi, 8(1).

Bulut, Y. ve Tanıyıcı, Ş. (2008), Türkiye' de Belediye Meclis üyelerinin temsil ediciliği ve kent yönetimindeki etkisi. (Ed. H. Özgür, M. Kösecik), Yerel Yönetimler Üzerine Yazılar 2 içinde (s. 354-373), Ankara: Nobel Yayınları.

Byrne, T. (1985). Local Government in Britain: Everyone's guide to how it all works, Suffolk: Penguin.

Canpolat, H. (1999). İngiltere'de mahalli idareler. Dünyada mahalli idareler içinde (s.319-340) .Ankara: İçişleri Bakanlığ1 Mahalli İdareler Genel Müdürlüğü,

Coulson, A. (2004). Local politics, central power: The future of representative local government in England. Local Government Studies, 30(4), 467-480.

Çadırcı, M. (1970). Türkiye'de muhtarlık teşkilatının kurulması üzerine bir inceleme. Belleten, 34(135), 409-420.

Çiftepınar, R. (2006). Yeni il özel idaresi yasasına eleştirel bir bakış. Yasama Dergisi, 2, 123-145.

Çoban A. ve Kılıç S. (2009). Türkiye'de yerel yönetimlerin çevreye yönelik politikaları: Konya Selçuklu Belediyesi SELKAP örneği. Selçuk Üniversitesi Sosyal Bilimler Enstitüsü Dergisi, 22, 117-130.

Çukurçayır, A. M. (2012). Siyasal katılma ve yerel demokrasi. Konya: Çizgi Kitabevi Yayınları.

Çukurçayır, A. M. ve Eşki, H. (2001), Kamu Hizmeti Sunumunda Yeni Yöntemler. S. ̈̈. İ̈BF Sosyal ve Ekonomik Araştırmalar Dergisi, 1-2, 89-109.

Department of Economic and Social Affairs (2006). United Kingdom Public administration country profile. 25.05.2019 tarihinde http://unpan1.un.org/intradoc/groups/public/documents/un/unpan023325.pdf adresinden erişildi.

Engels, F. (2010). Ingiltere'de emekçi sımıfı durumu (Çev.:Y. Fincanc1). Ankara: Sol Yayınları.

Erdem, N. (2015). Çevre sorunlarının yerel yönetimler kapsamında incelenmesi. Sosyal ve Beşeri Bilimleri Dergisi, 7(1), 16-32.

Eroğul, C. (1999). Devlet yönetimine katılma hakkı. Ankara: İmge Kitabevi.

Eryılmaz, B. (2015). Kamu yönetimi. Kocaeli: Umuttepe Yayınları.

Fırat, A.S. (2008). Yoksulluk, kentlerde suç artışı ve kent merkezlerinde özel güvenlik hizmetleri verilmesi. Gazi Üniversitesi İ.I.B.F. Dergisi, 10(3), 201-228. 
Foulkes, D. (1995). Adminisrative law. Eight Edition, London: Butterworths.

Goodnow, F. J.(1887). Local government in England. Political Science Quarterly. The Academy of Political Science, 2(4) 638-665.

Government Of United Kingdom (2019). 23.12.2019 tarihinde https:/www.gov.uk/government/how-government-works ve https://www.gov.uk/government/collections/provisional-local-government-finance-settlement-england-2020-to-2021. Adresinden erişildi.

Görmez, K. (1989). Yerel demokrasi ve Türk belediyeciliği. Ankara: Hizmet İş Sendikası Yayınları.

Görmez, K. (2015). Yerel yönetimler. Ankara: Orion Kitabevi.

Gözler, K. (2000). Türk Anayasa Hukuku. Bursa: Ekin Kitabevi Yayınları.

Gözler, K. (2010). İdare Hukukuna giriş. Güncelleştirilmiş 21. Baskı, Bursa: Ekin Yayınevi.

Gözübüyük, Ş. (1971). Türkiye'nin idari yapısı. 2. Baskı, Ankara: TODAİE Yayınları.

Gül, H. ve Özgür H.(2004). Adem-i merkeziyetçilik ve merkezi yönetim-yerel yönetim ilişkileri. (Ed.: M. Acar ve H. Özgür), Çă̆daş Kamu Yönetimi II, Ankara: Nobel Yayınevi.

Güler, B. A. (1992). Yerel yönetimler liberal açıklamalara eleştirel bir bakış. Ankara: TODAİE Yayınları.

Güler, B. A. (2013). Yerel yönetimler liberal açıklamalara eleştirel yaklaşım. Ankara: İmge Kitabevi.

Güler, Z. (2010). Sosyal demokrasi ve Türkiye. İstanbul: Siyah Beyaz Yayınları.

Hill, D. M. (1974). Democratic theory and local government. Published by London: Allen and Unwin.

Hobsbawm, E. J. (1987). Sanayi ve imparatorluk. Ankara: Dost Yayınları.

İnaç H. ve Ünal, F. (2006). İngiltere'de yerel yönetimler. Dumlupunar Üniversitesi Sosyal Bilimler Enstitüsü Dergisi, 125-140.

Kama, S. (2016). Parlamenter hükümet sistemi olarak Westminister Modeli: Britanya örneği üzerine bir deneme. Marmara Üniversitesi Hukuk Fakültesi Hukuk Araştırmaları Dergisi, 22(2),161-201.

Karasu, K. (2004). İngiltere. (Yay. Haz.: Bi. Ayman Güler, O. Karahanoğulları, K. Karasu, A. A. Dikmen, Ö. Akın, E. Tellal, N. E. Keskin, T. Çınar, S. Esen, M. N. Kutlu), Kamu Yönetimi Ülke Incelemeleri içinde (s. 87-181) Ankara: A.Ü. SBF Kamu Yönetimi Araştırma ve Uygulama Merkezi Yayını.

Kavruk, H. (2002). Anakent'e Bakış Türkiye'de anakent belediyeciliği ve kent hizmetlerinin yönetimi. Ankara: Hikmet-İş Sendikası Yayınları. 
Kaypak, Ş., Yılmaz, V., ve Bimay, M.(2017). Dijital çağda yerel yönetimler. Süleyman Demirel Üniversitesi Iktisadi ve İdari Bilimler Fakültesi Dergisi 22(Kayfor15 Özel Sayıs1), 1798-1813.

Kazanc1, M. (1983). Yerel yönetimler üzerine bir kaç not. Amme İdare Dergisi, 36-51. Keleş, R. (1998). Yerinden yönetim ve siyaset. İstanbul: Cem Yayınevi.

Kızıler N. ve Çetinkaya, Ö. (2015). Seçilmiş ülkeler kapsamında Türkiye'deki belediyelerin merkeze bağımlılıklarının analizi. Marmara Üniversitesi Siyasal Bilimler Dergisi, 135-165.

Koçak, Y. (2013). Türkiye'de yerel yönetimler. Ankara: Siyasal Kitabevi.

Kösecik, M. (2000). 4 Mayıs 2000 büyükşehir belediyesi seçimlerinin getirdikleri: Londra' da yeni dönem. Çă̆daş Yerel Yönetimler, 69-81.

Laffin, M. (2008). Local government modernisationin England: A critical review of the lgma evaluation studies. Local Government Studies,109-125.

Lijphart, A. (2012). Patterns of democracy government forms and performance in thirtysix countries, Second Edition, New Haven \& London: Yale University Press. 09.06.2019 tarihinde https://eedu.nbu.bg/pluginfile.php/830138/mod resource/content/.pdf adresinden erişildi.

Lundin, S. (2015). The closest governments to the people, division of governmental studies and services Washington State University, Washington.

Martin, S. (2011). Local government improvement in England:Policies, Progress and Prospects. Commonwealth Journal of Local Governance, Issue 8/9, MayNovember, 69-83.09.07.2019 tarihinde https://epress.lib.uts.edu.au/journals/index.php/cilg/article/view/2412. adresinden erişildi.

Mashamaite, K. ve Lethoko M. (2018). Role of the South African local government in local economic development. International Journal Of Ebusiness And Egovernment Studies, 10(1), 114-128.

Nadaroğlu, H. (1986). Mahalli idareler. Üçüncü Baskı, İstanbul: Beta Yayınevi.

Northern Ireland Exceutive [NIE]. (2019). Topics: Your Executive. 23.12.2019 tarihinde $\quad$ https://www.northernireland.gov.uk/topics/your-executive adresinden erişildi.

Oakland, J. (2002). British Civilization, rutledge: London and New York. 15.12.2019 tarihinde https://www.academia.edu/7482517/British Civilization- An Introduction John Oakland pdf. adresinden erişildi.

Okutan, E. (2009). Yerel yönetimler ve sivil toplum örgütlerinin gelişmiş işbirliği: İngiltere örneği. Sayıştay Dergisi, 91-108.

Ortayll, İ. (1985). Tanzimat'tan Cumhuriyete yerel yönetim geleneği. İstanbul:Hil Yayınları 
Öcal, S. (2001) İngiltere'de yerel yönetimler ve thatcherism. Yayınlanmamış Yüksek Lisans Tezi, Ankara Üniversitesi, Ankara.

Ökmen, M., Baştan, S. ve Yllmaz, A. (2004). Kamu yönetiminde yeni yaklaşımlar ve bir yönetişim faktörü olarak yerel yönetimler. (Ed. A. Yılmaz-M. Ökmen), Kuramdan Uygulamaya Kamu Yönetimi içinde (s. 23-80), Ankara: Gazi Kitabevi.

Ökmen M. ve Parlak B. (2015). Yerel yönetimlerde yeni vizyonlar. Bursa: Ekin Yayınevi.

Önder Ö. (2013). Yerelleşme ve yerel demokrasinin güçlendirilmesi bağlamında yerel katılım. Uluslararası Yönetim İktisat Ve İşletme Dergisi, 9(18), 311-326.

Özel, M., Eren, V. (2012). Merkezi yönetim ve piyasa kıskacındaki yerel yönetimler: Karşılaştırmalı bir inceleme. International Journal of Human Sciences. 9(2), 1379-1401.

Parlak, B. (2014). Avrupa Birliği Perspektifinden merkezi yönetim-yerel yönetim ilişkileri. Tesam Akademi Dergisi, 7-40.

Pirenne, H. (1994). Ortaçă̆ kentleri (Çev. Ş. Karadeniz). İstanbul: İletişim Yayınları.

Sakal, M. (2000). Türkiye'de yerel yönetimlerde yeniden yapılanma sorunu: Tarihsel perspektiften bir değerlendirme. Süleyman Demirel Üniversitesi İ.I.B.F. Dergisi, 119-140.

Sandford, M. (2016). Local government in England: Structures. House of Commons Library.

Seyidanlığlu, M. (2010). Tanzimat döneminde modern belediyeciliğin doğuşu. İstanbul: İş Bankası Yayınları.

Sezer, Ö. ve Vural, T. (2010). Kamu hizmetlerinin sunumunda devletin değişen rolü ve merkezi yönetim ile yerel yönetimler arasında yetki ve görev paylaşımı, Maliye Dergisi, 159, 204-219.

Sobacı, M. Z. (2005). Yeniden yapılanma sürecinde il özel idarelerinin dünü, bugünü ve geleceği üzerine değerlendirmeler. Çă̆daş Yerel Yönetimler, $14(4), 31-50$.

Stewart, J. (2014). An era of continuing change: Reflections on local government in England 1974-2014. Local Government Studies, 40(6), 835-850.

Stigler, G. (1957). The tenable range of functions of local government. (Ed.: Joint Economic Committee, Subcommittee on Fiscal Policy), Federal Expenditure Policy for Economic Growth and Stability içinde (s.213-19), U.S. Congress, Washington, DC: U.S. Government Printing Office, 28.11.2019 tarihinde https://fraser.stlouisfed.org adresinden erişildi.

Şengül, R. (2014), Yerel yönetimler. 4. Baskı, Kocaeli: Umuttepe Yayınları. 
Özen, S. (2008). Birleşik Krallık'ta kamu yönetimi reformları (1979- 2008). Кamu İdarelerinde Stratejik Yönetim Projesi Raporu, 1. Bask1, Ankara: Matus Basımevi. 08.11.2019 tarihinde http://www.sp.gov.tr/upload/xSpKutuphane/files/U3QcS+BirlesikKralliktaKamuYonetimiReformlari.pdf.adresinden erişildi.

T.C. Cumhurbaşkanlığı (2019). Cumhurbaşkanı görev ve yetkileri. 02.11.2019 tarihinde https://www.tccb.gov.tr/cumhurbaskanligi/gorev yetki/. adresinden erişildi.

TBMM (2019). Karşllaştırmalı hükümet sistemleri: Parlamenter sistem (Almanya, Güney Afrika, Hindistan, İtalya, İngiltere, Japonya Örnekleri). 13.11.2019 tarihinde https://www.tbmm.gov.tr/yayinlar/parlamenter sistem.pdf. adresinden erişildi.

Toksöz, F., Ali E. Ö., Öykü U., Levent K., Gülay A. ve Nilüfer A. (2009). Yerel yönetim sistemleri: Türkiye Fransa İspanya İtalya Polonya Çek Cumhuriyeti, İstanbul: TESEV Yayınları.

Tortop, N. (1992). Londra Büyükşehir yönetimi. Çağdaş Yerel Yönetimler Dergisi, 3-7. Tortop, N. (1994). İngiltere'de yerel idare bütçeleri. Çağdaş Yerel Yönetimler Dergisi, 47-52.

Tortop, N., Aykaç, B., Yaman, H. ve Özer, M. Akif. (2006). Mahalli idareler. Ankara: Nobel Yayınları.

Tunçer, P. (2011). Yerel yönetimlerde değişim yöntemi. Bursa: Ekin Yayınevi.

Türkoğlu, İ. (2009). Yerel yönetimlerde mali reform arayışlarn: Türkiye'de belediyelerde mali özerklik ve belediye başkanlarının mali özerklik algllaması. Ankara: Maliye Bakanlığı Strateji Geliştirme Daire Başkanlığı Yayını.

Urhan, V. F. (2008). Türkiye'de yerel yönetimlerin yeniden yapılandırılması. Sayıştay Dergisi, 70, 85-101.

Vodyanitskaya, E. (2016). Local government. Max Planck foundation for international peace and the rule of law. (Ed. R. Grote, F. Lachenmann, R. Wolfrum), Oxford University Press .

Wilson, D. ve Game, C. (2011). Local government in the United Kingdom, Basingstoke: Macmillan.

Wickwar, H. (1970). The political theory of local government. Carolina: Universty Of South Carolina Pres. 
Wollmann, H. (2012). Local government reforms in (seven) european countries: between convergent and divergent, conflicting and complementary developments. Local Government Studies, 38(1), 41-70, 10.06.2019 tarihinde https://www. researchgate. net/ publication /232862600Local Government Reforms in Seven European Countries BetweenConvergent and Divergent Conflicting and Complementary Developments adresinden erişildi.

Worthy, B., Amos, J., Hazell, R. and Bourke, G. (2011). Town hall transparency? The impact of the freedom of information act 2000 on local government in England. ESRC Economic ESocial Research Council, The Constitution Unit Department of Political Science University College London. 13.12.2019 tarihinde https://www.ucl.ac.uk/constitution-unit/sites/constitution-unit/files/town-hall-transparency.pdf. adresinden erişildi.

Yamaç, M. (2014). İngiltere'de yerel yönetimler. Namık Kemal Üniversitesi, Sosyal Bilimler Enstitüsü, Sosyal Bilim Metinleri, No: 4, 21.07.2019 tarihinde http://bhi.nku.edu.tr/basinyonetim/resim/images/editorresimleri/413/files/Sbm 04 2014.pdf. tarihinden erişildi.

Yaylı, H. (2009). Türkiye'de belediyelerin yeniden yapılandırlması. Kırıkkale: Kırıkkale Belediyesi Yayınları.

Zhumashov, Y. (2016). Rural local government system in Kazakhstan: Recent Issues. International Review of Management and Marketing, 6(S5), 211-220.

\section{Kaynakça Bilgisi / Citation Information}

Bulut, Y. ve Bimay, M. (2020). Karşılaştırmalı yerel yönetimler analizi: İngiltere ve Türkiye örnekleri. OPUS-Uluslararası Toplum Araştırmalart Dergisi, 16(29), 2263-2298. DOI: 10.26466/opus.735795 